DOE/RL-2000-21

Revision 0

\title{
Nonradioactive Air Emissions Notice of Construction Application for the Central Waste Complex for Storage of Vented Waste Containers
}

Prepared for the U.S. Department of Energy

Assistant Secretary for Environmental Management

Project Hanford Manacement Contractor for the

U.S. Department of Energy under Contract DE-ACO6-96RL13200

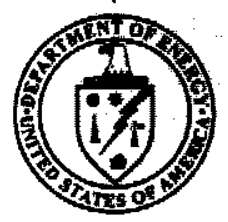

United States

Department of Energy

P.0. Box 550

Richland, Washington 99352 


\section{Nonradioactive Air Emissions Notice of Construction Application for the Central Waste Complex for Storage of Vented Waste Containers}

Date Published

April 2000

Prepared for the U.S. Department of Energy

Assistant Secretary for Environmental Management

Project Hanford Management Contractor for the

U.S. Department of Energy under Contract DE-AC06-96RL13200

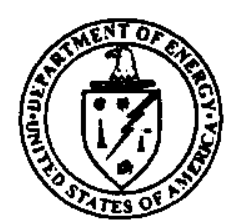

\section{United States}

Department of Energy

P.O. Box 550

Richland, Washington 99352

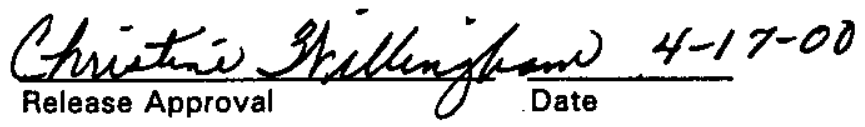


2 TERMS

$6 \quad 1.0$ INTRODUCTION. $1-1$

FACILITY IDENTIFICATION AND LOCATION/BACKGROUND INFORMATION

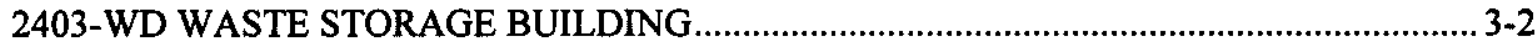

FLAMMABLE AND ALKALI METAL MIXED WASTE STORAGE MODULES ................. 3-2

WASTE STORAGE PAD.

WASTE RECEIVING AND STAGING AREA

Flammable and Alkali Metal Mixed Waste Storage Modules.

AIRBORNE EMISSIONS MONITORING SYSTEMS

SUMMARY

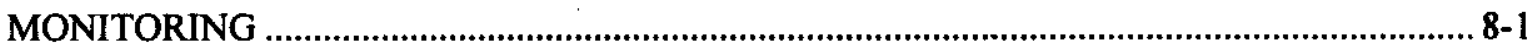

NEW SOURCE REVIEW FOR CRITERIA POLLUTANTS (WAC 173-400)

SCHEDULE 


\section{ATTACHMENTS}

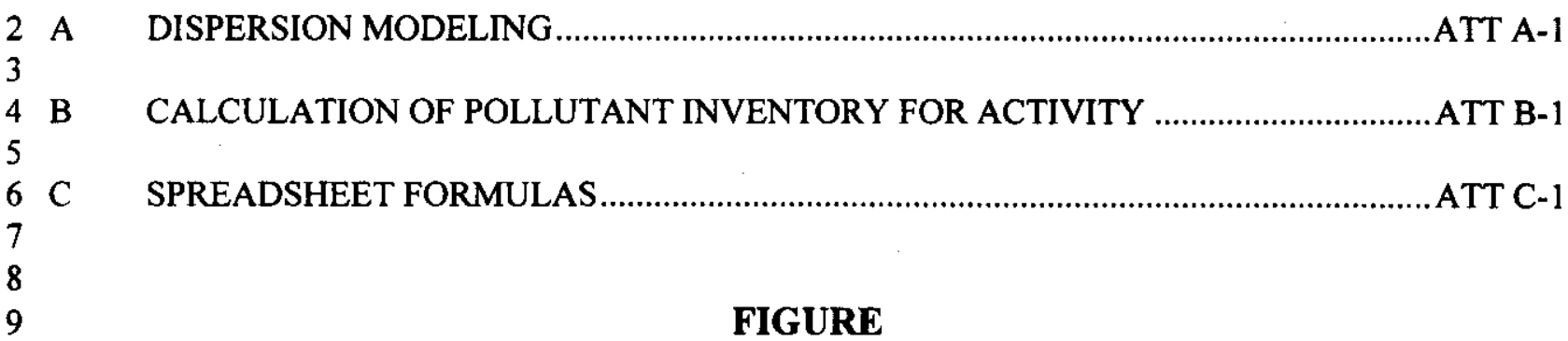

10 Figure 3-1. Central Waste Complex, 200 West Area.. F3-1 11 
4 ALARA

5 ASIL

6 AOP

7

8 BACT

9

10 CAS

11 CFR

12 CWC

13

14 DOE-RL

15

$16^{\circ}$ Ecology

17

18 LLBG

19

20 NOC

21 NSR

22

23 PCB

24 PIN

25

26 SQER

27 SWITS

28

29 TAP

30 T-BACT

31 TOMES

32

33 TRU

34 TSCA

35 TSD

36

37 VOC

38

39 WAC

40

\section{TERMS}

as low as reasonably achievable

acceptable source impact level

air operating permit

best available control technology

Chemical Abstract System

Code of Federal Regulations

Central Waste Complex

U.S. Department of Energy, Richland Operations Office

Washington State Department of Ecology

Low-Level Burial Grounds

notice of construction

new source review

polychlorinated biphenyls

package identification number

small quantity emission rate

Solid Waste Information Tracking System

toxic air pollutant

toxics-best available control technology

Toxicology Occupational Medicine and Environmental Series

(Hanford Technical Library online database)

transuranic

Toxic Substances Control Act of 1976

treatment, storage, and/or disposal

volatile organic compound

Washington Administrative Code 


\section{METRIC CONVERSION CHART}

Into metric units

Out of metric units

\begin{tabular}{|c|c|c|c|c|c|}
\hline If you know & Multiply by & To get & If you know & Multiply by & To get \\
\hline \multicolumn{3}{|c|}{ Length } & \multicolumn{3}{|c|}{ Length } \\
\hline Inches & 25.40 & millimeters & Millimeters & 0.0393 & inches \\
\hline Inches & 2.54 & centimeters & Centimeters & 0.393 & inches \\
\hline Feet & 0.3048 & meters & Meters & 3.2808 & feet \\
\hline Yards & 0.914 & meters & meters & 1.09 & yards \\
\hline Miles & 1.609 & kilometers & kilometers & 0.62 & miles \\
\hline \multicolumn{3}{|c|}{ Area } & \multicolumn{3}{|c|}{ Area } \\
\hline square inches & 6.4516 & $\begin{array}{l}\text { square } \\
\text { centimeters }\end{array}$ & $\begin{array}{l}\text { square } \\
\text { centimeters }\end{array}$ & 0.155 & square inches \\
\hline square feet & 0.092 & square meters & square meters & 10.7639 & square feet \\
\hline square yards & 0.836 & square meters & square meters & 1.20 & square yards \\
\hline square miles & 2.59 & $\begin{array}{l}\text { square } \\
\text { kilometers }\end{array}$ & $\begin{array}{l}\text { square } \\
\text { kilometers }\end{array}$ & 0.39 & square miles \\
\hline acres & 0.404 & hectares & hectares & 2.471 & acres \\
\hline \multicolumn{3}{|c|}{ Mass (weight) } & \multicolumn{3}{|c|}{ Mass (weight) } \\
\hline ounces & 28.35 & grams & grams & 0.0352 & ounces \\
\hline pounds & 0.453 & kilograms & kilograms & 2.2046 & pounds \\
\hline short ton & 0.907 & metric ton & metric ton & 1.10 & short ton \\
\hline \multicolumn{3}{|c|}{ Volume } & \multicolumn{3}{|c|}{ Volume } \\
\hline fluid ounces & 29.57 & milliliters & milliliters & 0.03 & fluid ounces \\
\hline quarts & 0.95 & liters & liters & 1.057 & quarts \\
\hline gallons & 3.79 & liters & liters & 0.26 & gallons \\
\hline cubic feet & 0.03 & cubic meters & cubic meters & $\overline{35.3147}$ & cubic feet \\
\hline cubic yards & 0.76456 & cubic meters & cubic meters & 1.308 & cubic yards \\
\hline \multicolumn{3}{|c|}{ Temperature } & \multicolumn{3}{|c|}{ Temperature } \\
\hline Fahrenheit & $\begin{array}{l}\text { Subtract } 32 \\
\text { then } \\
\text { multiply by } \\
5 / 9 \text { th }\end{array}$ & Celsius & Celsius & $\begin{array}{l}\text { multiply by } \\
9 / 5 \text { ths, then } \\
\text { add } 32\end{array}$ & Fahrenheit \\
\hline \multicolumn{3}{|c|}{ Force/Pressure } & \multicolumn{3}{|c|}{ Force/Pressure } \\
\hline $\begin{array}{l}\text { pounds per } \\
\text { square inch }\end{array}$ & 6.895 & kilopascals & kilopascals & 0.14504 & $\begin{array}{l}\text { pounds per } \\
\text { square inch }\end{array}$ \\
\hline
\end{tabular}

Source: Engineering Unit Conversions, M. R. Lindeburg, PE., Second Ed., 1990, Professional

Publications, Inc., Belmont, California. 


\section{NONRADIOACTIVE AIR EMISSIONS NOTICE OF CONSTRUCTION APPLICATION FOR THE CENTRAL WASTE COMPLEX FOR STORAGE OF VENTED WASTE CONTAINERS}

\subsection{INTRODUCTION}

5 This Notice of Construction (NOC) application is submitted for the storage and management of waste 6 containers at the Central Waste Complex (CWC) stationary source. The CWC stationary source consists 7 of multiple sources of diffuse and fugitive emissions, as described herein. This NOC is submitted in 8 accordance with the requirements of Washington Administrative Code (WAC) 173-400-110 (criteria 9 pollutants) and 173-460-040 (toxic air pollutants), and pursuant to guidance provided by the Washington 10 State Department of Ecology (Ecology).

11

12 Transuranic (TRU) mixed waste containers at CWC are vented to preclude the build up of hydrogen 13 produced as a result of radionuclide decay, not as safety pressure releases.

- Storage and inspection

- Transfer and staging

- Packaging

- Treatment

- Sampling.

This NOC application is intended to cover all existing storage structures within the current CWC treatment, storage, and/or disposal (TSD) boundary, as well as any storage structures, including waste storage pads and staging areas, that might be constructed in the future within the existing CWC boundary. 
DOE/RL-2000-21, Rev. 0

$04 / 2000$

2

3

4

This page intentionally left blank. 
DOE/RL-2000-21, Rev. 0

$04 / 2000$

\subsection{STATE ENVIRONMENTAL POLICY ACT}

2 The State Environmental Policy Act Environmental Checklist for the CWC was submitted October 31, 31991 (DOE/RL-91-17).

4 
This page intentionally left blank. 


\title{
3.0 FACILITY IDENTIFICATION AND LOCATION/BACKGROUND INFORMATION
}

\begin{abstract}
The CWC stationary source is located in the 200 West Area of the Hanford Site (Figures 3-1). CWC provides storage and treatment for dangerous, mixed, radioactive, and Toxic Substances Control Act (TSCA) of 1976 waste generated on or off the Hanford Facility. Treatment includes sorption and solidification of free liquids, neutralization of corrosive materials, and stabilization and encapsulation of solid waste matrices.
\end{abstract}

The CWC stationary source currently consists of the following diffuse and fugitive emission sources:

- 2401-W Waste Storage Building

- 2402-W Waste Storage Buildings

- 2403-WA through WC Waste Storage Buildings

- 2403-WD Waste Storage Building

- 2404-W Waste Storage Buildings

- Flammable and Alkali Metal Mixed Waste Storage Modules

- Waste Storage Pad and Waste Receiving and Staging Area.

Descriptions of the diffuse and fugitive emission sources are provided in the following sections. Additional structures and pads of the type described in this document might be added as necessary to meet the demands of waste management activities. The addition of any structures or pads at CWC is intended to be covered by this NOC application.

Pre-engineered steel structures of the types described in the following sections preclude the possibility of establishing and maintaining a negative pressure within the structures because all the structures have numerous in-leakage points, such as frequently opened doors as well as the assembly of structural components. These components were not designed to be air tight, but rather to protect stored containers from the weather. Because a negative pressure cannot be established and maintained within the structures, there is no single point of controlled exhaust on any of the structures. This NOC application assumes that any existing or planned storage pads or staging areas, within the bounding conditions of this application, also are considered a source of diffuse and fugitive emissions.

\subsection{1-W WASTE STORAGE BUILDING}

The 2401-W Waste Storage Building, a single pre-engineered steel structure for dangerous, mixed, radioactive, and/or TSCA waste, is approximately 50 feet wide by 80 feet long by 20 feet high with a clear span in the 50 -foot direction. The foundation is integrated into a perimeter concrete curb. Ramps are across the curb for loading and unloading operations. The 2401-W Waste Storage Building accommodates approximately 1,07255 -gallon equivalent containers.

\section{$3.2 \quad 2402-W$ WASTE STORAGE BUILDINGS}

The 2402-W Waste Storage Buildings are pre-engineered steel structures for storage of dangerous, mixed, radioactive; and TSCA waste that are approximately 50 feet wide by 80 feet long by 24 feet high at the eave, with a clear span in the 50-foot direction. The metal structures have two rollup truck doors and two personnel doors. The foundation is integrated into a perimeter concrete curb. Ramps are across the curb for loading and unloading operations. The 2402-W Waste Storage Buildings accommodate 
approximately 1,072 55-gallon equivalent containers. Compatible combinations of waste can be placed in any one of the buildings according to the building loading schedules.

\subsection{3-WA THROUGH WC WASTE STORAGE BUILDINGS}

The 2403-WA through 2403-WC Waste Storage Buildings are steel-supported, sheet-metal-covered structures for dangerous, mixed, radioactive, and/or TSCA waste that are approximately 170 feet wide by 200 feet long by 20 feet high at the eave. The 2403-WA through 2403-WC Waste Storage Buildings each accommodate approximately 11,600 55-gallon equivalent containers. Compatible combinations of dangerous, mixed, radioactive, and/or TSCA waste can be placed in any one containment quadrant according to the 2403-W Series Waste Storage Buildings loading schedules.

\subsection{3-WD WASTE STORAGE BUILDING}

The 2403-WD Waste Storage Building is a steel-supported, sheet-metal-covered structure approximately 170 feet wide by 325 feet long by 20 feet high that accommodates approximately 17,500 55-gallon equivalent containers of dangerous, mixed, radioactive, and/or TSCA waste. Compatible combinations of dangerous, mixed, radioactive, and/or TSCA waste can be placed in any one containment quadrant according to the 2403-WD Waste Storage Building loading schedules.

\section{$3.5 \quad 2404-W$ WASTE STORAGE BUILDINGS}

The 2404-WA Waste Storage Buildings are steel-supported, sheet-metal-covered structures approximately 120 feet wide by 180 feet long by 20 feet high that each accommodate approximately 4,600 55-gallon equivalent containers of dangerous, mixed, radioactive, and/or TSCA waste. Compatible combinations of these waste types can be placed in any one containment quadrant according to the 2404-W Series Waste Storage Buildings loading schedules.

\subsection{FLAMMABLE AND ALKALI METAL MIXED WASTE STORAGE MODULES}

The Flammable and Alkali Metal Mixed Waste Storage Modules are pre-engineered structures ranging in size from 10 feet wide by 14 feet long by 8.5 feet high to 10 feet wide by 32 feet long by 8 feet high. These storage modules accommodate, depending on size, from 27 to 5855 -gallon equivalent containers.

All the Flammable and Alkali Metal Mixed Waste Storage Modules are constructed of steel and are coated inside with a chemical-resistant epoxy paint or have a corrosion-resistant covering. Three of the Flammable Mixed Waste Storage Modules have fire-retardant plywood floors and ceilings within the metal skin. The remaining Flammable and Alkali Metal Mixed Waste Storage Modules are constructed of metal.

The Flammable and Alkali Metal Mixed Waste Storage Modules are designed to meet all the storage requirements for ignitable, reactive, and corrosive mixed, radioactive, and/or TSCA waste of this type. Most of the Flammable and Alkali Metal Mixed Waste Storage Modules currently store low-level radioactively contaminated flammable and alkali metal waste. Only compatible waste occupies any one storage module at any one time. Selected Flammable Mixed Waste Storage Modules have been identified for TRU flammable waste. The remaining Flammable and Alkali Metal Mixed Waste Storage 
1 Modules, and any future Flammable and Alkali Metal Mixed Waste Storage Modules, could be modified

2 for a specific use depending on storage needs.

3

4

\subsection{WASTE STORAGE PAD}

6 The 7-inch to 8-inch thick concrete Waste Storage Pad is designed to support loading up to 1.25 pounds 7 per square inch and accommodates approximately 1,700 55-gallon equivalent containers. The Waste

8 Storage Pad is curbed with 6 inches of concrete. The Waste Storage Pad is provided with an access ramp 9 and a rainwater collection and removal system.

\subsection{WASTE RECEIVING AND STAGING AREA}

13 The Waste Receiving and Staging Area, an asphalt pad approximately 200 feet long and 150 feet wide, is 14 used for the container handling and staging of waste destined for various storage buildings. Access for 15 loading and unloading operations is provided. 
DOE/RL-2000-21, Rev. 0

$04 / 2000$

This page intentionally left blank. 


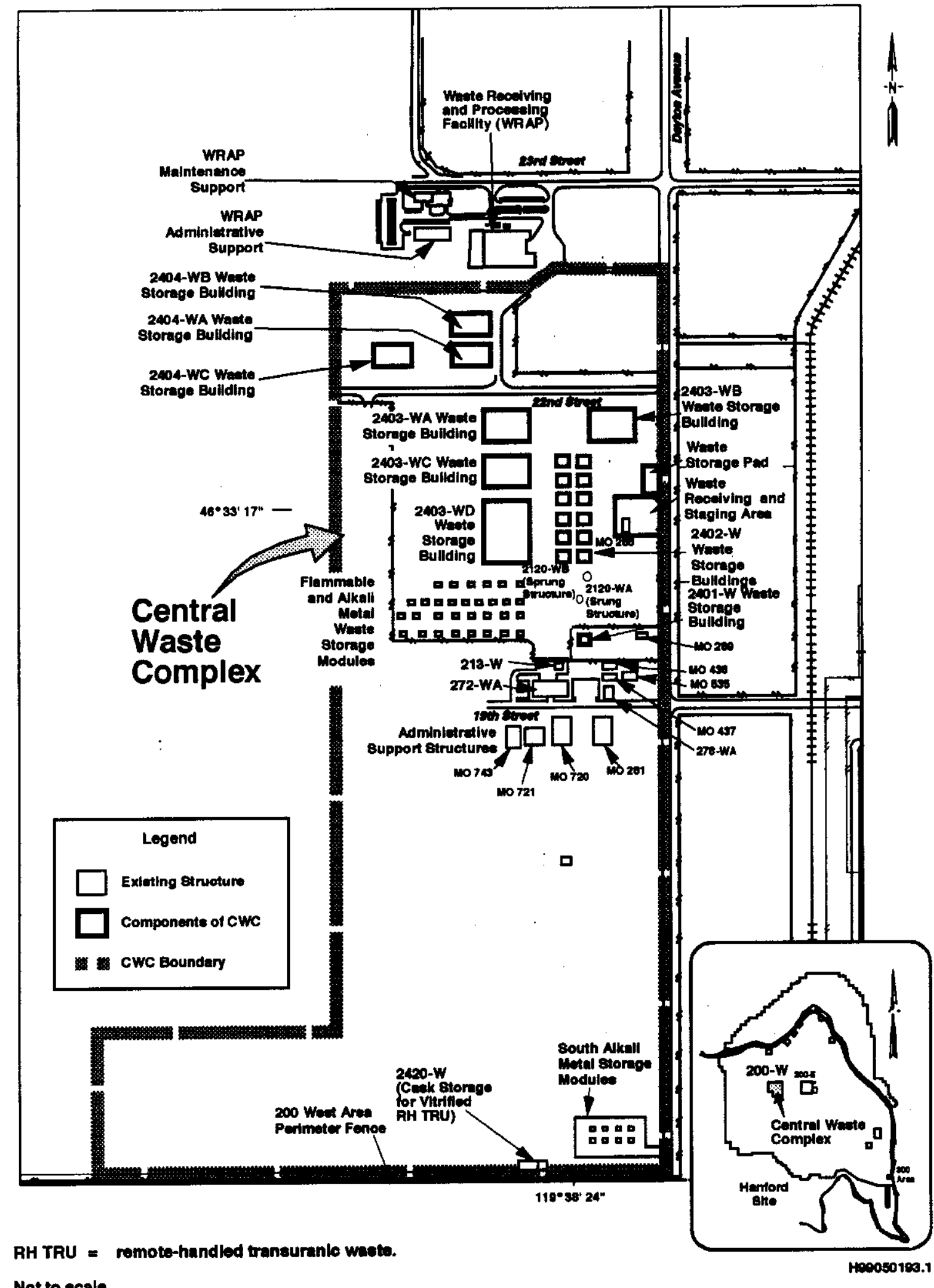

Figure 3-1. Central Waste Complex, 200 West Area. 
DOE/RL-2000-21, Rev. 0

$04 / 2000$

This page intentionally left blank.

6 
2 The following briefly discusses the operations that occur or can occur at CWC. No activities are

3 conducted routinely that would cause resuspension of potential pollutants.

4

All waste accepted for storage at CWC is packaged in approved containers (U.S. Department of Transportation and/or U.S. Department of Energy), unless alternate packages are dictated by the size, shape, or form of waste [49 Code of Federal Regulations (CFR) 173] (e.g., boxes). Exterior surfaces of 55-gallon metal containers either are painted or galvanized in accordance with specifications.

Before liquids are accepted for storage, the liquids are (1) bound by sorption or (2) sealed in leakresistant containers (e.g., labpacks or overpacks) and surrounded by sorbent material in a 55-gallon container or other approved container to facilitate eventual treatment of the liquid. The labpack/overpack configuration results in a smaller container(s) packaged with an appropriate sorbent to sorb at least twice the maximum amount of liquid potentially present. Waste with the potential to form condensate during storage contains sufficient sorbent in the bottom of the container to sorb any condensate formed.

Gas generation is controlled to prevent pressurization exceeding 1.5 atmospheres and combustible gas concentrations exceeding the lower explosive limit for up to 20 years of storage. To prevent the potential buildup of gases, vents such as Nucfil ${ }^{\otimes *}$, vent clips, or other approved devices are used.

The majority of the vented containers within the CWC are provided with a NucFil ${ }^{\circledR}$, however, vent clips have been used in past operations. Some older containers could even have a 'permeable gasket'. Vent clips and/or permeable gaskets are no longer installed on newly generated waste.

A vent clip, a non-filtered device with gaps approximately 3 microns in size, was designed to prevent complete sealing between the drum and the drum lid. Most vented containers are fitted with NucFil ${ }^{\circledR}$ filter vents designed to provide high-efficiency filtration of particulates. These filters include a porous carbon/carbon composite of non-activated carbon fibers that restrict particulate releases and provide 99.95 percent efficiency per manufacturer specifications. The same is not true regarding gaseous/vapor contaminants. These vents are designed to allow air to flow in or out of the container at any time there is a pressure differential relative to ambient conditions, resulting in very low volume, nearly continuous flow.

Before receipt at CWC, all 55-gallon containers are closed by the onsite generating unit or offsite generator by means of a neoprene gasket, steel lid, locking ring, locking ring bolt, and a lock nut torqued tight or by other available methods to meet applicable U.S. Department of Transportation packaging requirements. On receipt, each container or group of containers is inspected before acceptance by CWC operations personnel for damage, proper closure, marking, and proper accompanying documentation.

The container packaging, module construction, and container handling are designed to maintain containment of the waste, provide retrieval capability of damage-free and contamination-free containers, limit storage intrusion, and limit human exposure to dangerous waste and hazardous materials. Retrieved containers from the Low-Level Burial Grounds (LLBG) can be assayed, $\mathrm{x}$-rayed, and headspace analyzed for volatiles and semivolatile compounds.

\footnotetext{
${ }^{*} \mathrm{NucFil}^{\circledR}$ is a Registered Trademark of the Nuclear Filter Technology, Incorporated.
} 
1

Vented containers primarily contain mixed and/or TRU waste. All TRU waste to be retrieved from the LLBG and transported to the CWC is considered to be newly generated and will be vented. Before August 1998, there was no administrative way to distinguish a vented container from a sealed container. Since August of 1998, all vented containers accepted at CWC have been flagged in the Solid Waste Inventory Tracking System (SWITS) database enabling the containers to be tracked. An unknown percentage of other containers, while not specifically vented, are not considered sealed containers. Process knowledge has this number conservatively bounded by 20 percent of the total current inventory.

\subsection{FACILITY CAPACITY}

As of October 19, 1999, there were approximately 27,000 containers of waste stored within the CWC. The total capacity of the buildings and modules is approximately 88,500 containers. Data are managed within the SWITS database (Attachment B) and are available upon request for the toxic air pollutant (TAP) inventory of the containers stored/managed at CWC.

NOTE: Because of the volume of the SWITS database, summaries have been included in this NOC application.

\subsection{TEMPERATURE AND GAS COMPOSITION OF ALL EMISSIONS}

Temperatures are ambient and not controlled. The gas composition of emissions are as described in Section 7.0. Data relative to the gaseous inventory in each containēr have been developed. Any gaseous emissions would be from some, or all, of that inventory. Data include the following and are summarized in Attachment B and Attachment C:

- Package identification number (PIN \#) - From SWITS

- Chemical Abstract System number (CAS \#) - From SWITS

- Chemical component text name - From SWITS

- Acceptable source impact level (ASIL) in micrograms per cubic meter - From WAC 173-460

- Chemical component weight in pounds - From SWITS

- Density - from TOMES database at Hanford Technical Library

- Vapor pressure - from TOMES

- Molecular weight - from TOMES

- Small quantity emission rate (SQER) class (A or B) - from WAC 173-460

- Comments (to clarify evaluate column). 


\subsection{VENTILATION AND AIRBORNE EMISSIONS POLLUTION CONTROL SYSTEMS}

A description of the ventilation/control systems is provided in the following sections for the diffuse and fugitive emission sources that comprise the CWC stationary source. There could be up to 88,500 emission units (i.e., containers) within the seven diffuse and fugitive emission sources that comprise the CWC stationary source. The diffuse and fugitive emission sources are as follows:

- 2401-W Waste Storage Building

- 2402-W Waste Storage Buildings

- 2403-WA through WC Waste Storage Buildings

- 2403-WD Waste Storage Building

- 2404-W Waste Storage Buildings

- Flammable and Alkali Metal Mixed Waste Storage Modules

- Waste Storage Pad and Waste Receiving and Staging Area.

\subsection{DIFFUSE AND FUGITIVE EMISSION SOURCES VENTILATION SYSTEMS}

The structures (diffuse and fugitive emission sources) described in this section were designed and constructed to protect waste containers (emission units) from the weather, not to provide containment for potential emissions. As such, the original purpose of the wall and roof exhausters was to exhaust the air from contamination due to fork lifts and other internal combustion vehicle emissions, seasonal heat buildup, personnel comfort, etc.

\subsubsection{1-W Waste Storage Building}

The 2401-W Waste Storage Building is maintained at atmospheric pressure. The ventilation system consists of two wall exhausters, rated at 3,000 cubic feet per minute, that provide approximately four air changes per hour. These fans need not operate continuously.

\subsubsection{2-W Waste Storage Buildings}

The 2402-W Waste Storage Buildings are maintained at atmospheric pressure. The ventilation system for each building consists of two wall exhausters, rated at 3,000 cubic feet per minute, that provide approximately four air changes per hour. These fans need not operate continuously.

\subsubsection{3-WA Through WC Waste Storage Buildings}

The 2403-WA through WC Waste Storage Buildings are maintained at atmospheric pressure. The ventilation system for each building consists of four wall exhausters, each rated at approximately 13,340 cubic feet per minute, that provide approximately four air changes per hour. These fans need not operate continuously. 


\subsubsection{3-WD Waste Storage Building}

The 2403-WD Waste Storage Building is maintained at atmospheric pressure. The ventilation system consists of four wall exhausters, each rated at approximately 21,680 cubic feet per minute each, that provides approximately four air changes per hour. These fans need not operate continuously.

\subsubsection{4-W Waste Storage Buildings}

The 2404-W Waste Storage Buildings are maintained at atmospheric pressure. The ventilation system for each building consists of two roof-mounted exhausters, each rated at a minimum of 16,775 cubic feet per minute, that provide approximately four air changes per hour. These fans need not operate continuously.

\subsubsection{Flammable and Alkali Metal Mixed Waste Storage Modules}

Currently, there are 39 storage modules equipped with natural draft ventilation, including inlet vents near the floors and exhaust vents near the ceilings.

\subsubsection{Waste Storage Pads and Waste Receiving and Staging Areas}

No additional controls for emissions for any of the storage structures and/or pad and staging area within the CWC stationary source are proposed (refer to Section 5.2.3).

\subsection{AIRBORNE EMISSIONS CONTROL SYSTEMS}

Emissions from CWC actually emanate from vented containers, which Ecology has identified as individual emissions units (diffuse and fugitive emission sources). In turn, the individual emission units are stored within structures or on a pad. The following discussion addresses controls for diffuse and fugitive emissions sources and individual emissions units.

\subsubsection{Individual Emissions Units}

Closed containers provide no potential for emissions. Therefore, closed containers are not considered in the following discussion.

All TRU waste containers are vented to prevent accumulation of potentially explosive concentrations of hydrogen gas. In addition, containers with organic materials (e.g., plant matter) also are vented to allow for the release of decomposition gases. Other constituents (e.g., toxic and/or radiological) can be vented on a case-by-case basis depending on the hazards present.

Containers are vented with one of three devices: vent clips, NucFil ${ }^{\circledR}$ filters, or a permeable gasket. The majority of the vented containers within the CWC are provided with NucFil ${ }^{\circledR}$ filters; however, vent clips have been used in past operations. Some older containers might even have a permeable gasket. Vent clips and/or permeable gaskets are no longer installed on newly generated waste. As of August 1998, all vented containers received by $\mathrm{CWC}$ are vented with a NucFil ${ }^{\circledR}$ filter. All three of these vent devices were designed to control particulate emissions from within the containers. However, as described in 
1 Section 4.0, no activities routinely are conducted within CWC that could cause resuspension of

2 particulates. Therefore, these devices are not proposed as being required for particulate control. All

3 potential emissions of concern in this NOC application are based on the assumption that the emissions

4 are either volatile organic compounds (VOCs) and/or volatile TAPs. There are no potential emissions

5 from nonvolatile TAPs.

There are no physical controls in place for emissions of VOCs or volatile TAPs from the emission units; and no controls are proposed, based on the low levels of emissions (Section 7.0). A general cost/benefit evaluation showed high economic cost for installation on 88,500 emission units (Section 5.2.3), with little to no value added in improvements towards maintaining the ambient air quality.

\subsubsection{Diffuse and Fugitive Emissions Sources (Storage Structures)}

As a source of diffuse and fugitive emissions, the CWC storage structures currently have no single controlled exhaust (point of emissions). Without a single controlled exhaust point, there are no controls for emissions in place at any of the CWC storage structures.

\subsubsection{Proposed Controls Conclusion}

The feasibility of controls for emissions from the storage structures that comprise the CWC stationary source was considered. Because the CWC storage structures (storage modules and pad) were not designed for or constructed of materials to maintain a negative pressure, it would be necessary to dismantle the structures and build completely new structures. Given that the total emissions of any single volatile TAP from the entire CWC stationary source (i.e., all diffuse and fugitive emission sources combined) do not exceed the corresponding acceptable source impact level (ASIL) value (Section 7.0), the expenditure of funds to dismantle existing structures and build new ones would not have a corresponding positive environmental impact.

However, it is proposed that administrative controls be implemented for VOC and/or volatile TAP emissions from the CWC stationary source. Using solid waste acceptance methods, each container is screened against the list of regulated TAPs to verify that the total emissions of each individual volatile TAP from CWC does not exceed its associated SQER value. TAPs that do not have an associated SQER are evaluated to verify that the constituents are not volatile

It is proposed that the previous discussion constitutes best available control technology (BACT) and toxics-best available control technology (T-BACT) for CWC based on the following.

- Processes conducted in CWC that would encourage emissions of regulated constituents are minimized, i.e., storage and sampling and treatment activities (refer to Section 1.0).

- Emissions of volatile TAPs from the emission units (i.e., containers) stored within or on CWC stationary source collectively have been defined as diffuse and fugitive.

- Installation of controls on the structures would not provide enough additional environmental benefit to be economically feasible.

- Installation of controls on each of the 88,500 emission units that could comprise the CWCs total container inventory would not provide enough additional environmental benefit to be economically feasible. 
1

- Total emissions of individual volatile TAPs from the CWC stationary source are and will be less than the ASIL value associated with each TAP, as shown by a review of Appendix B.

- The total theoretical release of VOCs, as a criteria pollutant, from vented containers at CWC (Section 7.0) is calculated to be less than the 4,000 pound exemption threshold value for VOCs identified in WAC 173-00-10(5)(d). This does not account for the fact that once emitted from a container, the potential to further emit VOCs does not exist.

Waste received at $\mathrm{CWC}$ is evaluated through the solid waste acceptance process. This process includes a review of the dangerous constituents to ensure that ASIL and SQER are not exceeded such that if released instantaneously and completely to the environment would exceed the SQER associated with that TAP. No additional controls for TAPs are proposed for the emission units and diffuse and fugitive emission sources comprising the CWC stationary source. 
2 As discussed in Section 5.0, CWC has no controlled exhaust on any of the diffuse and fugitive emission

3 sources within the TSD unit boundary. As a result of the conclusions provided in Section 5.0, proposing

4 no controls, and the low levels of VOC and/or volatile TAP emissions presented in Section 7.0, no

5 monitoring and/or sampling systems are proposed for CWC.

6

7 To meet the air operating permit (AOP) application (DOE/RL-95-07) requirement for periodic

8 monitoring (i.e., gap filling), CWC personnel use SWITS (described in Section 4.0) for both individual

9 emissions units stored within and/or on the CWC diffuse and fugitive emission sources that make up the

10 CWC stationary source.

11

12 The number of vented containers received by $\mathrm{CWC}$ each calendar year is tracked as follows.

13

$14^{~}$ - If the number of vented containers is less than 1,000 , the total VOC emissions are assumed to be less than 0.5 ton, which is rounded down to zero for annual reporting purposes (per guidance from Ecology).

- If the number of vented containers exceeds 1,000 , a query will be performed on the SWITS database to calculate total VOC emissions.

This query was performed for calendar year 1999. Less than 500 vented containers were managed and stored at CWC (including containers that simply were moved from one building to another, but were generated in a previous year). The total VOCs potentially emitted from those containers were calculated to be less than 240 pounds. When the containers that were generated in previous years were excluded from the calculations, the total emissions of VOCs were less than 50 pounds. It is assumed that the VOCs are released in the year generated, and are no longer available for release in subsequent years.

It is proposed that an annual assessment of SWITS be conducted to document compliance that no monitoring and/or sampling systems are needed. This assessment will be reported annually beginning as part of the calendar year 1999 nonradioactive inventory of airborne emissions. 
DOE/RL-2000-21, Rev. 0

$04 / 2000$

This page intentionally left blank. 


\subsection{EMISSIONS ESTIMATION}

2 The following estimate of the hypothetical maximum emissions of 'criteria pollutants' and TAPs

3 (regulated under WAC 173-400 and WAC 173-460) was derived based on the following.

4

5 Given the activities conducted at CWC, only volatile TAPS and/or VOCs provide a potential for

6. emissions.

7

8 - CWC activities do not generate particulate emissions from the management and storage of containers

9 within the diffuse and fugitive emission sources described herein.

- CWC stationary source does not have on hand, in vented containers, at any one time, a quantity of any regulated volatile TAPs, such that if the entire inventory of those compounds were hypothetically released over the appropriate associated averaging periods, those compounds would not exceed the associated ASIL values.

- The amount of each TAP that would have to be released to exceed the ASIL for offsite concentration was established as an ASIL threshold.

Based on this information and using a 'back calculation', the computer program model, "Industrial Source Complex 3"(ISC3) was performed using the ASIL value for each TAP that is also a volatile compound. The spreadsheet used for estimated potential emissions is further described in Attachment C. The resultant emissions estimate was based on the following:

- The maximum theoretical release of each TAP (in pounds per year for a single container) was calculated based on the following factors:

- 55-gallon equivalent capacity per container

- 1 percent by weight (average) of the container contents is the TAP

- Density, vapor pressure, and molecular weight of the TAP

- Container had one vapor space exchange per day

- Average temperature assumed to be $25^{\circ}$ Centigrade

- Each TAP was evaluated against the ASIL threshold to see if it was possible to exceed the threshold if 20 percent of the CWC 88,500-container capacity were vented drums containing that TAP. None of the TAPs exceeded the threshold.

Total VOCs are the only criteria pollutant (WAC 173-400) expected to be emitted from CWC. The new source review (NSR) exemption threshold level for total VOCs is 2 tons per year per stationary source.

In October 1999 , the CWC stationary source inventory of approximately 27,000 containers was evaluated for VOCs as follows:

- Per WAC 173-400-030(84), VOCs mean any compounds that participates in atmospheric have negligible photochemical reactivity, are excluded from this definition (e.g., acetone, methylene chloride, methyl chloroform). 
The total theoretical release of VOCs from the current inventory was calculated as less than 6,000 pounds (generated over 20 years of SWITS data), assuming all 25,000 containers (excluding 2,000 labpacked containers assumed to be sealed) are vented.

- The maximum number of containers generated in a single year was less than 5,000 (approximately 20 percent). Less than 20 percent of the containers are vented, so the maximum annual release over the past 20 years is conservatively calculated to be less than 240 pounds per year

$14(6,000 \times 5,000 / 25,000 \times 20 \%)$.

- Extrapolated to the remaining capacity of 61,500 additional containers $(88,500$ containers maximum

Therefore, it is concluded that NSR, pursuant to WAC 173-400, is not required for CWC and it is proposed that CWC be exempted from NSR pursuant to WAC 173-400-110(5)(d). It also is concluded

23 the ASIL associated with that constituent. 
2 CWC is a source of diffuse and fugitive emissions. As a source of diffuse and fugitive emissions, none 3 of the storage structures within the CWC TSD unit boundary have controlled exhaust (single point[s] of

4 emission[s]). Not having controlled exhaust, none of the structures within the CWC TSD unit boundary

5 have emissions control or sampling equipment in place.

6

7 The vented containers in CWC constitute individual emissions units. Containers are considered vented

8 when the container is equipped with a vent clip, a permeable gasket, or a NucFil ${ }^{\circledR}$ filter. As of August

9 1998, all vented containers accepted by CWC must be vented with a NucFil ${ }^{\circledR}$ filter. NucFil ${ }^{\circledR}$ filters are

$1099.95 \%$ effective against particulates. The highest concentrations of VOCs are received by CWC in

11 labpacks that preclude the possibility of emissions as these containers are considered sealed.

\subsection{NEW SOURCE REVIEW FOR CRITERIA POLLUTANTS (WAC 173-400)}

As a source of diffuse and fugitive emissions, CWC has no controlled exhaust on any of the storage structures within the CWC boundary. As a result of the evaluation provided in Section 5.0, no controlled exhaust on any of the CWC storage structures is proposed; therefore, no exhaust monitoring/sampling systems are proposed.

To satisfy the AOP application requirement for periodic monitoring (i.e., gap filling), CWC personnel use an inventory tracking system. The number of vented containers received by CWC each calendar year is tracked as described in Section 6.0. If the number of vented containers is less than 1,000, the total VOC emissions are assumed to be less than 0.5 ton, which is rounded down to zero for annual reporting purposes. If the number of vented containers received at CWC in a calendar year exceeds 1,000 , a query will be performed on the SWITS database to calculate total VOC emissions. An annual assessment of the results of that tracking effort will be reported. 
1 VOCs, based on the current inventory (October 1999), conservatively is estimated at less than 2240 pounds. Extrapolated to the remaining capacity of approximately 61,500 containers (total

3 capacity of approximately 88,500 containers), the maximum release of VOCs for the additional

4 capacity is less than 3,000 pounds. This estimate conservatively assumes that the additional

5 remaining capacity is filled in a single year. Therefore, it is proposed that this activity be

6 eligible for the NSR exemption, pursuant to WAC 173-400-110(5)(b) for the CWC stationary

7 source. 
2 Operations are an on-going part of the solid waste activities on the Hanford Site. Activities occur or can

3 occur 365 days a year, 24-hours a day. This includes movement of up to approximately 88,500

4 (maximum number of containers in CWC at capacity) emission units containing any of the Class $\mathrm{A}$ or

5 Class B constituents regulated under WAC 173-460 within the CWC stationary source, at the time of

6 application issuance. A detailed schedule of containers to be moved or relocated on any given day is

7 available onsite from Solid Waste Project Operations. 
DOE/RL-2000-21, Rev. 0

$04 / 2000$

1

2

3

4

5

This page intentionally left blank. 
DOE/RL-2000-21, Rev. 0

$04 / 2000$

\subsection{REFERENCES}

DOE/RL-91-17, Hanford Central Waste Complex-Radioactive Mixed Waste Storage Facility Dangerous Waste Permit Application included a State Environmental Policy Act Environmental Checklist.

DOE/RL-95-07, Hanford Site Air Operating Permit Application, U.S. Department of Energy, Richland, Washington.

7

8 ISC3, Unit Concentration Factors from Industrial Source Complex Dispersion Models, September 27, 9 1996, Westinghouse Hanford Company, Richland, Washington. 
DOE/RL-2000-21, Rev. 0

$04 / 2000$

1

2

3

4

This page intentionally left blank. 
3 The theoretical estimate of emissions in Section 7.0, was based on the Unit Concentration Factors from 4 Industrial Source Complex Dispersion Models (ISC3). Averaging times specified in WAC 174-460-150 5 were assigned based on whether or not a chemical was Class A or Class B as appropriate.

6

7 Because of the volume of SWITS data, hard copies are available onsite for review. 
DOE/RL-2000-21, Rev. 0

$04 / 2000$

This page intentionally left blank. 
As of October 19, 1999, there were approximately 27,000 containers of waste stored within the CWC, including approximately 2,000 labpacks. The SWITS database shows that less than 6,000 pounds of VOCs could have been released from the 25,000 containers over the 20 years of SWITS data. The current total capacity of the buildings and modules is approximately 88,500 containers. The maximum number of containers generated in a single year was less than 5,000 (approximately 20 percent). A conservative, best engineering judgment, estimate shows less than 20 percent of containers currently stored at CWC are vented, so the maximum annual release over the past 20 years conservatively is calculated to have been less than 240 pounds per year. Extrapolating the pounds of VOCs out to 88,500 containers yields a value of approximately 3,000 pounds. This is below the WAC $173-400$ trigger level for criteria pollutants. While the number of vented containers is expected to increase with the retrieval of TRU waste from the LLBG, SWITS queries show the TRU waste is radioactive only (not mixed waste).

There are approximately 600 regulated chemicals in WAC 173-460. Approximately 200 of those chemicals have been identified as currently being stored within CWC. Given that future onsite and offsite deliveries of chemicals cannot be known at this time, it is possible that any of the regulated TAPs could be received. Historically, the range of chemicals stored at CWC has remained fairly constant.

The following regulated TAPs, from WAC 173-460, have been sorted by Chemical Abstracts Service number (CAS \#). Those TAPs with an asterisk in the last column ('In inventory') currently are stored in CWC. The current inventory has been identified using the SWITS database. Future additions of chemicals will be tracked within the SWITS database and could include those currently not in the CWC inventory.

\begin{tabular}{|c|c|c|c|}
\hline CAS \# & Substance & ASIL & In inventory \\
\hline --- & Coke oven emissions & 0.0016000 & \\
\hline$+\cdots$ & Cotton dust, raw & 0.67 & \\
\hline$-\cdots$ & Fibrous glass dust & 33.00 & \\
\hline$-\cdots$ & Fine mineral fibers & 33.00 & \\
\hline $\overrightarrow{---}$ & Glycol ethers & ** & \\
\hline --- & Hexane, other isomers & 5900.00 & \\
\hline$-\cdots$ & Iron salts, soluble as Fe & 3.30 & \\
\hline 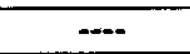 & Rubber solvent (Naphtha) & 5300.00 & \\
\hline$\cdots$ & Welding fumes & 17.00 & \\
\hline$-\cdots$ & Primary aluminum smelter uncontrolled roof vent & 0.0013 & \\
\hline$-\cdots$ & polyaromatic hydrocarbon (PAH) emissions & 0.0013 & \\
\hline--- & (Note: Quantify according to WAC $173-460-050(4)(d)$ ) & 0.0013 & \\
\hline $100-00-5$ & p-Nitrochlorobenzene & 2.00 & \\
\hline $100-01-6$ & p-Nitroaniline & 10.00 & \\
\hline $100-02-7$ & 4-Nitrophenol & ** & * \\
\hline $10025-67-9$ & Sulfur monochloride & 18.00 & \\
\hline $10025-87-3$ & Phosphorus oxychloride & 2.10 & \\
\hline $10026-13-8$ & Phosphorus pentachloride & 2.80 & \\
\hline $10035-10-6$ & Hydrogen bromide & 33.00 & \\
\hline $100-37-8$ & Diethylaminoethanol & 170.00 & * \\
\hline
\end{tabular}




\begin{tabular}{|c|c|c|c|}
\hline CAS \# & Substance & ASIL & In inventory \\
\hline $100-41-4$ & Ethyl benzene & 1000.00 & $*$ \\
\hline $100-42-5$ & Styrene & 1000.00 & * \\
\hline $100-44-7$ & Benzyl chloride & 17.00 & \\
\hline $10049-04-4$ & Chlorine dioxide & 0.20 & \\
\hline $100-54-3$ & Hexane (n-Hexane) & 200.00 & \\
\hline $100-61-8$ & N-Methyl aniline & 7.30 & * \\
\hline $100-63-0$ & Phenylhydrazine & 1.50 & \\
\hline $100-74-3$ & N-Ethylmorpholine & 77.00 & \\
\hline $10102-43-9$ & Nitríc oxide & 100.00 & \\
\hline $101-14-4$ & 4,4'-Methylenebis (2-Chloroaniline) (MBOCA) & 0.7 & \\
\hline $101-68-8$ & Methylene bis(phenyl isocyanate) & 0.20 & \\
\hline $101-77-9$ & 4,4-Methylene dianiline & 2.7 & * \\
\hline $101-77-9$ & Polyaromatic hydrocarbon (PAH) emissions & 0.0004800 & * \\
\hline $101-84-8$ & Phenyl ether & 23.00 & \\
\hline $10210-68-1$ & Cobalt carbonyl as Co & 0.33 & \\
\hline $102-54-5$ & Dicyclopentadienyl iron & 33.00 & * \\
\hline $102-81-8$ & 2-N-Dibutylaminoethanol & 47.00 & \\
\hline $10294-33-4$ & Boron tribromide & 33.00 & \\
\hline $105-46-4$ & sec-Butyl acetate & 3200.00 & \\
\hline $105-60-2$ & Caprolactam, dust & 3.30 & \\
\hline $105-60-2$ & Caprolactam, vapor & 67.00 & \\
\hline $106-35-4$ & Ethyl butyl ketone & 780.00 & \\
\hline $106-46-7$ & 1,4-Dichlorobenzene & 1.5000000 & * \\
\hline $106-49-0$ & $\mathrm{p}$-Toluidine & 29.00 & \\
\hline $106-50-3$ & p-Phenylenediamine & 0.33 & * \\
\hline $106-51-4$ & Quinone & 1.50 & \\
\hline $106-87-6$ & Vinyl cyclohexene dioxide & 200.00 & \\
\hline $106-88-7$ & 1,2-Epoxybutane & 20.00 & * \\
\hline $106-89-8$ & Epichlorohydrin & 0.8300000 & * \\
\hline $106-92-3$ & Allyl glycidyl ether (AGE) & 77.00 & \\
\hline $106-93-4$ & Ethylene dibromide (dibromethane) & 0.0045000 & \\
\hline $106-97-8$ & Butane & 6300.00 & * \\
\hline $106-99-0$ & 1,3-Butadiene & 0.0036000 & \\
\hline $107-02-8$ & Acrolein & 0.02 & \\
\hline $107-05-1$ & Allyl chloride & 1.00 & \\
\hline $107-06-2$ & 1,2-Dichloroethane (ethylene chloride) & 0.0380000 & * \\
\hline $107-07-3$ & Ethylene chlorohydrin & 11.00 & \\
\hline $107-13-1$ & Acrylonitrile & 0.0150000 & \\
\hline $107-15-3$ & Ethylene diamine & 83.00 & * \\
\hline $107-18-6$ & Allyl alcohol & 17.00 & \\
\hline $107-19-7$ & Propargyl alcohol & 7.70 & * \\
\hline $107-20-0$ & Chloroacetaldehyde & 11.00 & * \\
\hline $107-21-1$ & Ethylene glycol & 420.00 & * \\
\hline $107-31-3$ & Methyl formate & 820.00 & \\
\hline $107-41-5$ & Hexylene glycol & 400.00 & * \\
\hline $107-49-3$ & TEPP & 0.16 & \\
\hline $107-66-4$ & Dibutyl phosphate & 29.00 & * \\
\hline $107-87-9$ & Methyl propyl ketone & 2300.00 & \\
\hline $107-98-2$ & Propylene glycol monomethyl ether & 2000.00 & * \\
\hline $108-03-2$ & 1-Nitropropane & 20.00 & * \\
\hline
\end{tabular}




\begin{tabular}{|c|c|c|c|}
\hline CAS \# & Substance & ASIL & In inventory \\
\hline $108-05-4$ & Vinyl acetate & 200.00 & * \\
\hline $108-10-1$ & Methyl isobutyl ketone (MIBK) & 680.00 & * \\
\hline $108-11-2$ & Methyl isobutyl carbinol & 350.00 & \\
\hline $108-18-9$ & Diisopropylamine & 67.00 & \\
\hline $108-20-3$ & Isopropyl ether & 3500.00 & \\
\hline $108-21-4$ & Isopropyl acetate & 3500.00 & \\
\hline $108-24-7$ & Acetic anhydride & 67.00 & * \\
\hline $108-31-6$ & Maleic anhydride & 3.30 & \\
\hline $108-43-0$ & Chlorophenols & 0.1800000 & * \\
\hline $108-44-1$ & m-Toluidine & 29.00 & * \\
\hline 108-46-3 & Resorcinol & 150.00 & \\
\hline $108-83-8$ & Diisobutyl ketone & 480.00 & \\
\hline $108-84-9$ & sec-Hexyl acetate & 980.00 & \\
\hline $108-87-2$ & Methylcyclohexane & 5400.00 & * \\
\hline $108-88-3$ & Toluene & 400.00 & * \\
\hline $108-90-7$ & Chlorobenzene & 150.00 & * \\
\hline $108-91-8$ & Cyclohexylamine & 140.00 & \\
\hline $108-93-0$ & Cyclohexanol & 690.00 & \\
\hline $108-94-1$ & Cyclohexanone & 330.00 & * \\
\hline $108-95-2$ & Phenol & 63.00 & * \\
\hline $108-98-5$ & Phenyl mercaptan & 7.70 & \\
\hline $109-59-1$ & Isopropoxyethanol & 350.00 & \\
\hline $109-60-4$ & n-Propyl acetate & 2800.00 & \\
\hline 109-66-0 & Pentane & 6000.00 & * \\
\hline $109-73-9$ & n-Butylamine & 50.00 & \\
\hline $109-79-5$ & n-Butyl mercaptan & 6.00 & \\
\hline $109-86-4$ & 2-Methoxyethanol & 20.00 & * \\
\hline $109-87-5$ & Methylal & 10000.00 & * \\
\hline $109-89-7$ & Diethylamine & 100.00 & \\
\hline $109-94-4$ & Ethyl formate & 1000.00 & \\
\hline $109-99-9$ & Tetrahydrofuran & 2000.00 & * \\
\hline $110-12-3$ & Methyl isoamyl ketone & 780.00 & * \\
\hline $110-19-0$ & Isobutyl acetate & 2400.00 & * \\
\hline $110-43-0$ & Methyl n-amyl ketone & 780.00 & * \\
\hline $110-49-6$ & 2-Methoxyethyl acetate & 80.00 & \\
\hline $110-62-3$ & n-Valeraldehyde & 590.00 & \\
\hline $110-80-5$ & 2-Ethoxyethanol & 200.00 & * \\
\hline $110-82-7$ & Cyclohexane & 3400.00 & * \\
\hline $110-83-8$ & Cyclohexene & 3400.00 & * \\
\hline $110-86-1$ & Pyridine & 53.00 & * \\
\hline $110-91-8$ & Morpholine & 240.00 & * \\
\hline $111-15-9$ & 2-Ethoxyethyl acetate & 90.00 & * \\
\hline $111-30-8$ & Glutaraldehyde & 2.50 & \\
\hline $111-40-0$ & Diethylene triamine & 14.00 & $*$ \\
\hline $111-42-2$ & Diethanolamine & 43.00 & \\
\hline $111-44-4$ & Bis(2-chloroethyl)ether & 0.0030000 & * \\
\hline $111-65-9$ & Octane & 4700.00 & \\
\hline $111-76-2$ & 2-Butoxyethanol & 400.00 & * \\
\hline $111-84-2$ & Nonane & 3500.00 & * \\
\hline $114-26-1$ & Propoxur & 1.70 & \\
\hline
\end{tabular}




\begin{tabular}{|c|c|c|c|}
\hline CAS \# & Substance & ASIL & In inventory \\
\hline $115-29-7$ & Endosulfan & 0.33 & \\
\hline $115-86-6$ & Triphenyl phosphate & 10.00 & * \\
\hline $115-90-2$ & Fensulfothion & 0.33 & \\
\hline $117-81-7$ & Bis(2-ethylhexyl)phthalate (DEHP) & 2.5000000 & * \\
\hline $118-52-5$ & 1,3-Dichloro-5,5-Dimethyl hydantoin & 0.67 & \\
\hline $118-74-1$ & Hexachlorobenzene & 0.0022000 & * \\
\hline $118-96-7$ & 2,4,6-Trinitrotoluene & 1.70 & \\
\hline $1189-85-1$ & tert-Butyl chromate, as $\mathrm{CrO} 3$ & 0.33 & \\
\hline $119-93-7$ & 3,3-Dimethyl benzidine & 0.0038000 & \\
\hline $12079-65-1$ & Manganese cyclopentadienyl tricarbonyl & 0.33 & \# \\
\hline $120-80-9$ & Catechol & 77.00 & \\
\hline $120-82-1$ & 1,2,4-Trichlorobenzene & 120.00 & * \\
\hline $12108-13-3$ & Methylcyclopentadienyl manganese tricarbonyl & 0.67 & \\
\hline $121-14-2$ & 2,4-Dinitrotoluene & 5.00 & * \\
\hline $12125-02-9$ & Ammonium chloride fume & 33.00 & * \\
\hline $121-44-8$ & Triethylamine & 7.00 & * \\
\hline $12 !-45-9$ & Trimethyl phosphite & 33.00 & \\
\hline $121-69-7$ & Dimethylaniline & 83.00 & * \\
\hline $121-75-5$ & Malathion & 33.00 & \\
\hline $121-82.4$ & Cyclonite & 5.00 & \\
\hline $122-39-4$ & Diphenylamine & 33.00 & * \\
\hline $122-60-1$ & Phenyl glycidyl ether & 2000.00 & * \\
\hline $122-66-7$ & 1,2-Diphenylhydrazine & 0.0045000 & \\
\hline $123-19-3$ & Dipropyl ketone & 780.00 & \\
\hline $123-31-9$ & Hydroquinone & 6.70 & * \\
\hline $123-38-6$ & Propionaldehyde & *** & \\
\hline $123-42-2$ & Diacetone alcohol & 790.00 & * \\
\hline $123-51-3$ & Isoamyl alcohol & 1200.00 & 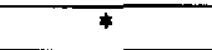 \\
\hline $123-86-4$ & n-Butyl acetate & 2400.00 & * \\
\hline $123-91-1$ & 1,4-Dioxane & 0.0320000 & * \\
\hline $123-92-2$ & Isoamyl acetate & 1700.00 & \\
\hline $124-40-3$ & Dimethylamine & 60.00 & \\
\hline $12604-58-9$ & Ferrovanadium dust & 3.30 & \\
\hline $126-73-8$ & Tributyl phosphate & 7.30 & * \\
\hline $126-98-7$ & Methylacrylonitrile & 9.00 & \\
\hline $126-99-8$ & p-Chloroprene & 120 & \\
\hline $127-18-4$ & Perchloroethylene (tetrachloroethylene) & 1.1000000 & * \\
\hline $127-19-5$ & Dimethyl acetamide & 120.00 & \\
\hline $128-37-0$ & 2,6-Ditert. butyl-p-cresol & 33.00 & \\
\hline $1300-73-8$ & Xylidine & 8.30 & \\
\hline $1303-86-2$ & Boron oxide & 33.00 & \\
\hline $1303-96-4$ & Borates, anhydrous & 3.30 & * \\
\hline $1303-96-4$ & Borates, decahydrate & 17.00 & 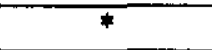 \\
\hline $1303-96-4$ & Borates, pentahydrate & 3.30 & * \\
\hline $1304-82-1$ & Bismuth telluride & 33.00 & \\
\hline $1304-82-1$ & Bismuth telluride Se doped & 17.00 & \\
\hline $1305-62-0$ & Calcium hydroxide & 17.00 & * \\
\hline $1305-78-8$ & Calcium oxide & 6.70 & * \\
\hline $1309-37-1$ & Iron oxide fume, $\mathrm{Fe} 2 \mathrm{O} 3$ as $\mathrm{Fe}$ & 17.00 & $*$ \\
\hline $1309-48-4$ & Magnesium oxide fume & 33.00 & \\
\hline
\end{tabular}




\begin{tabular}{|c|c|c|c|}
\hline CAS\# & Substance & ASIL & In inventory \\
\hline $1309-64-4$ & Antimony trioxide, as Sb & 1.70 & \\
\hline $1310-58-3$ & Potassium hydroxide & 6.70 & * \\
\hline $1310-73-2$ & Sodium hydroxide & 6.70 & * \\
\hline $131-11-3$ & Dimethylphthalate & 17.00 & * \\
\hline $13121-70-5$ & Cyhexatin & 17.00 & \\
\hline $1314-13-2$ & Zinc oxide, fume & 17.00 & $*$ \\
\hline $1314-62-1$ & Vanadium, as V2O5 & 0.17 & * \\
\hline $1314-80-3$ & Phosphorus pentasulfide & 3.30 & \\
\hline $1319-77-3$ & Cresol, all isomers & 73.00 & $*$ \\
\hline $1321-64-8$ & Pentachloronaphthalene & 1.70 & \\
\hline $1321-65-9$ & Trichloronaphthalene & 17.00 & \\
\hline $1321-74-0$ & Divinyl benzene & 180.00 & \\
\hline $1330-20-7$ & Xylenes (m-,o-,p-isomers) & 1500.00 & $*$ \\
\hline $133-06-2$ & Captan & 17.00 & \\
\hline $1332-21-4$ & Asbestos (Note: fibers/ml) & 0.0000040 & * \\
\hline $1333-86-4$ & Carbon black & 12.00 & * \\
\hline $1335-87-1$ & Hexachloronaphthalene & 0.67 & \\
\hline $1335-88-2$ & Tetrachloronaphthalene & 6.70 & \\
\hline 1336-36-3 & Polychlorinated biphenyls (PCB) & 0.0045000 & $*$ \\
\hline 1338-23-4 & Methyl ethyl ketone peroxide & 5.00 & * \\
\hline $133-90-4$ & Chloramben & *** & \\
\hline $13463-40-6$ & Iron pentacarbonyl, as $\mathrm{Fe}$ & 0.83 & \\
\hline $13494-80-9$ & Tellurium \& compounds as $\mathrm{Te}$ & 0.33 & \\
\hline $13530-65-9$ & Zinc chromates & 0.03 & * \\
\hline $136-78-7$ & Sesone & 33.00 & \\
\hline $137-05-3$ & Methyl 2-cyanoacrylate & 30.00 & \\
\hline $137-26-8$ & Thiram & 3.30 & \\
\hline $138-22-7$ & n-Butyl lactate & 83.00 & \\
\hline 13838-16-9 & Enflurane & 1900.00 & \\
\hline $1395-21-7$ & \begin{tabular}{|l|} 
Subtilisins \\
\end{tabular} & 0.00 & \\
\hline $140-88-5$ & Ethyl acrylate & 66.00 & * \\
\hline $141-32-2$ & Butyl acrylate & 170.00 & $*$ \\
\hline $141-43-5$ & Ethanolamine & 25.00 & * \\
\hline $141-66-2$ & Dicrotophos & 0.83 & \\
\hline $141-78-6$ & Ethyl acetate & 4800.00 & * \\
\hline $141-79-7$ & Mesityl oxide & 200.00 & * \\
\hline $142-64-3$ & Piperazine dihydrochloride & 17.00 & \\
\hline $142-82-5$ & Heptane (n-Heptane) & 5500.00 & 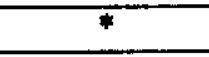 \\
\hline 144-62-7 & Oxalic acid & 3.30 & * \\
\hline 14484-64-1 & Ferbam & 33.00 & \\
\hline $1477-55-0$ & m-Xylene a,a'-diamine & 0.33 & \\
\hline 148-01-6 & Dinitolmide & 17.00 & \\
\hline 14977-61-8 & Chromyl chloride & 0.53 & \\
\hline $150-76-5$ & 4-Methoxyphenol & 17.00 & \\
\hline $151-56-4$ & Ethylenimine & 2.90 & \\
\hline $151-67-7$ & Halothane & 1300.00 & \\
\hline $1563-66-2$ & Carbofuran & 0.33 & \\
\hline $156-62-7$ & Calcium cyanamide & 1.70 & \\
\hline $1582-09-8$ & Trifluralin & *** & \\
\hline $16219-75-3$ & Ethylidene norbornene & 83.00 & \\
\hline
\end{tabular}




\begin{tabular}{|c|c|c|c|}
\hline CAS \# & Substance & ASIL & In inventory \\
\hline $1634-04-4$ & Methyl tert-butyl ether & 500.00 & \\
\hline $16752-77-5$ & Methomyl & 8.30 & \\
\hline $16842-03-8$ & Cobalt hydrocarbonyl & 0.33 & \\
\hline $16984-48-8$ & Fluorides, as $\mathrm{F}$ & 8.30 & \\
\hline $1746-01-6$ & $2,3,7,8$-Tetrachlorodibenzo-p-dioxin $(2,3,7,8$-TCDD) & 0.0000000 & \\
\hline $17702-41-9$ & Decaborane & 0.83 & \\
\hline $17804-35-2$ & Benomyl & 33.00 & \\
\hline $1912-24-9$ & Atrazine & 17.00 & \\
\hline $19287-45-7$ & Diborane & 0.37 & \\
\hline $1929-82-4$ & Nitrapyrin & 33.00 & \\
\hline $19624-22-7$ & Pentaborane & 0.043 & \\
\hline 2023600 & Platinum, Soluble salts as $\mathrm{Pt}$ & 0.01 & \\
\hline $2039-87-4$ & o-Chlorostyrene & 940.00 & \\
\hline $20816-12-0$ & Osmium tetroxide, as Os & 0.0053 & \\
\hline $2104-64-5$ & EPN & 1.70 & \\
\hline $21087.64-9$ & Metribuzin & 17.00 & \\
\hline $21351-79-1$ & Cesium hydroxide & 6.70 & \\
\hline $2179-59-1$ & Allyl propyl disulfide & 40.00 & \\
\hline $22224-92-6$ & Fenamiphos & 0.33 & \\
\hline $2234-13-1$ & Octachloronaphthalene & 0.33 & \\
\hline $2238-07-5$ & Diglycidyl ether & 1.70 & \\
\hline $2425-06-1$ & Captafol & 0.33 & \\
\hline $2426-08-6$ & n-Butyl glycidyl ether (BGE) & 440.00 & \\
\hline $25013-15-4$ & Vinyl toluene & 800.00 & \\
\hline $2551-13-7$ & Trimethyl benzene & 420.00 & \\
\hline $2551-62-4$ & Sulfur hexafluoride & 20000.00 & \\
\hline $25639-42-3$ & Methylcyclohexanol & 780.00 & \\
\hline $26140-60-3$ & Terphenyls & 16.00 & \\
\hline $26628-22-8$ & Sodium azide & 1.00 & \\
\hline $26952-21-6$ & Isocytl alcohol & 890.00 & \\
\hline $2698-41-1$ & o-Chlorobenylidene malonitrile & 1.30 & \\
\hline $2699-79-8$ & Sulfuryl fluoride & 67.00 & \\
\hline $287-92-3$ & Cyclopentane & 5700.00 & \\
\hline $29191-52-4$ & Anisidine (o-, $\mathrm{p}$ - isomers) & 1.70 & \\
\hline $2921-88-2$ & Chlorpyrifos & 0.67 & \\
\hline $2971-90-6$ & Clopidol & 33.00 & \\
\hline $298-00-0$ & Methyl parathion & 0.67 & \\
\hline 298-02-2 & Phorate & 0.17 & \\
\hline $298-04-4$ & Disulfuton & 0.33 & \\
\hline $299-84-3$ & Ronnel & 33.00 & \\
\hline $299-86-5$ & Crufomate & 17.00 & \\
\hline $300-76-5$ & Naled & 10.00 & \\
\hline $302-01-2$ & Hydrazine & 0.0002000 & * \\
\hline $309-00-2$ & Aldrin & 0.0002000 & \\
\hline $314-40-9$ & Bromacil & 33.00 & \\
\hline 319-84-6 & Hexachlorocyclohexane (Lindane) alpha BHC & 1.7 & \\
\hline $319-85-7$ & Hexachlorocyclohexane(Lindane) beta BHC & 1.7 & \\
\hline 319-85-7 & Lead compounds & 0.5 & \\
\hline $330-54-1$ & Diuron & 33.00 & \\
\hline $3333-52-6$ & Tetramethyl succinonitrile & 9.30 & \\
\hline
\end{tabular}




\begin{tabular}{|c|c|c|c|}
\hline CAS \# & Substance & ASIL & In inventory \\
\hline $333-41-5$ & Diazinon & $\quad 0.33$ & \\
\hline $334-88-3$ & Diazomethane & 1.10 & \\
\hline $3383-96-8$ & Temephos & 33.00 & \\
\hline $34590-94-8$ & Dipropylene glycol methyl ether & 2000.00 & \\
\hline $353-50-4$ & Carbonyl fluoride & 18.00 & \\
\hline $35400-43-2$ & Sulprofos & 3.30 & \\
\hline $3547-04-4$ & DDE (p,p'-dichlorodiphenyldichloroethylene) & 0.1000000 & \\
\hline $3687-31-8$ & Lead arsenate, as $\mathrm{Pb3}(\mathrm{A} 2 \mathrm{O} 4) 2$ & 0.50 & \\
\hline $3689-24-5$ & Sulfotep & 0.67 & \\
\hline $3825-26-1$ & Ammonium perfluorooctanoate & 0.33 & \\
\hline 4016-14-2 & Isopropyl glycidyl ether (IGE) & 790.00 & \\
\hline $4098-71-9$ & Isophorone diisocyanate & 0.15 & \\
\hline $4170-30-3$ & Crotonaldehyde & 20.00 & \\
\hline $420-04-2$ & Cyanamide & 6.70 & \\
\hline $460-19-5$ & Cyanogen & 67.00 & \\
\hline $463-51-4$ & Ketene & 2.90 & \\
\hline $463-58-1$ & Carbonyl sulfide & ** & \\
\hline $4685-14-7$ & Paraquat & 4.50 & \\
\hline $479-45-8$ & Tetryl & 5.00 & \\
\hline $50-00-0$ & Formaldehyde & 0.0770000 & 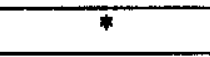 \\
\hline $50-29-3$ & DDT $(1,1,1$ Trichloro-2,2-Bis-(p-chlorophenyl)-ethane) & 0.0100000 & \\
\hline $50-32-8$ & Benzo(a)pyrene & 0.0004800 & * \\
\hline $504-29-0$ & 2-Aminopyridine & 6.30 & \\
\hline $506-77-4$ & Cyanogen chloride & 2.50 & * \\
\hline $509-14-8$ & Tetranitromethane & 27.00 & \\
\hline $510-15-6$ & \begin{tabular}{|l|} 
Chlorobenzilate \\
\end{tabular} & 0.2000000 & \\
\hline $51-12-5$ & Cyanides, as CN & 17.00 & \\
\hline $5124-30-1$ & Methylene bis (4-cyclo-hexylisocyanate) & 0.18 & \\
\hline $51-28-5$ & 2,4-Dinitrophenol & $* *$ & \\
\hline $51-79-5$ & Ethyl carbamate & $* *$ & \\
\hline $528-29-0$ & Dinitrobenzene, all isomers & 3.30 & \\
\hline $532-27-4$ & a-Chloroacetophenone & 1.10 & \\
\hline $534-52-1$ & Dinitro-o-cresol & 0.67 & \\
\hline $540-59-0$ & 1,2-Dichloroethylene & 2600.00 & \\
\hline $540-73-8$ & 1,2-Dimethylhydrazine & 4.0 & \\
\hline $540-84-1$ & 2,2,4-Trimethylpentane & ** & $*$ \\
\hline $540-88-5$ & tert-Butyl acetate & 3200.00 & \\
\hline $54-11-5$ & Nicotine & 1.70 & \\
\hline $541-85-5$ & Ethyl amyl ketone & 440.00 & \\
\hline $542-75-6$ & Dichloropropene & 20.00 & \\
\hline $542-88-1$ & Bis(chloromethyl)ether & 0.0000160 & \\
\hline $542-92-7$ & Cyclopentadiene & 680.00 & \\
\hline $55-18-5$ & N-Nitrosodiethylamine (diethylnitrosoamine)(DEN) & 0.0000230 & \\
\hline $552-30-7$ & Trimellitic anhydride & 0.13 & \\
\hline $55-38-9$ & Fenthion & 0.67 & \\
\hline $55-63-0$ & Nitroglycerin & 1.50 & \\
\hline $556-52-5$ & Glycidol & 250.00 & \\
\hline $55720-99-5$ & Chlorinated diphenyl oxide (hexachlorophenyl ether) & 1.70 & \\
\hline $558-13-4$ & Carbon tetrabromide & 4.70 & \\
\hline $56-23-5$ & Carbon tetrachloride & 0.0670000 & * \\
\hline
\end{tabular}


DOE/RL-2000-21, Rev. 0

04/2000

\begin{tabular}{|c|c|c|c|}
\hline CAS \# & Substance & ASIL & In inventory \\
\hline $563-12-2$ & Ethion & 1.30 & \\
\hline $563-80-4$ & Methyl isopropyl ketone & 2300.00 & \\
\hline $56-38-2$ & Parathion & 0.33 & \\
\hline $5714-22-7$ & Sulfur pentafluoride & 0.33 & \\
\hline $57-14-7$ & 1,1-Dimethylhydrazine & 4.00 & \\
\hline $57-\overline{24-9}$ & Strychnine & 0.50 & \\
\hline $57-57-8$ & B-Propiolactone & 5.00 & \\
\hline $57-74-9$ & Chlordane & 0.0027000 & * \\
\hline $583-60-8$ & o-Methylcyclohexanone & 760.00 & \\
\hline $584-84-9$ & 2,4-Toluene diisocyanate & 0.12 & * \\
\hline $58-89-9$ & Hexachlorocyclohexane (Lindane) gamma BHC & 0.0026000 & \\
\hline $591-78-6$ & 2-Hexanone (MBK) & 67.00 & * \\
\hline $591-78-6$ & Methyl n-butyl ketone & 67.00 & * \\
\hline $59355-75-8$ & Methyl acetylene-propadiene mixture (MAPP) & 5500.00 & \\
\hline $593-60-2$ & Vinyl bromide & 73.00 & \\
\hline $594-42-3$ & Perchloromethyl mercaptan & 2.50 & \\
\hline $594-72-9$ & 1,1-Dichloro-1-nitroethane & 40.00 & \\
\hline $600-25-9$ & 1-Chloro-1-nitropropane & 33.00 & \\
\hline $60-11-7$ & Dimethyl aminoazobenzene & $* *$ & \\
\hline $60-29-7$ & Ethyl ether & 4000.00 & * \\
\hline $603-34-9$ & Triphenyl amine & 17.00 & \\
\hline $60-34-4$ & Methyl hydrazine & 1.20 & \\
\hline $60-35-5$ & Acetamide & ** & \\
\hline $60-57-1$ & Dieldrin & 0.0002200 & \\
\hline $61-82-5$ & Amitrole & 0.06 & \\
\hline $624-83-9$ & Methyl isocyanate & 0.16 & \\
\hline $62-53-3$ & Aniline & 6.3000000 & \\
\hline $62-53-3$ & Aniline \& homologues & 1.00 & \\
\hline $626-17-5$ & m-Phthalodinitrile & 17.00 & \\
\hline $626-38-0$ & sec-Amyl acetate & 2200.00 & \\
\hline $627-13-4$ & n-Propyl nitrate & 360.00 & \\
\hline $62-73-7$ & Dichlorvas & 3.30 & \\
\hline $62-74-8$ & Sodium fluoroacetate & 0.17 & \\
\hline $62-75-9$ & N-Nitrosodimethylamine & 0.0000710 & \\
\hline $628-63-7$ & n-Amyl acetate & 1800.00 & * \\
\hline $628-96-6$ & Ethylene glycol dinitrate & 1.00 & \\
\hline $63-25-2$ & Carbaryl & 17.00 & \\
\hline $636-21-5$ & o-Toluidine hydrochloride & $0 . \overline{1400000}$ & \\
\hline $638 \cdot 21-1$ & Phenylphosphine & 0.77 & \\
\hline $64-17-5$ & Ethyl alcohol & 6300.00 & * \\
\hline 64-18-6 & Formic acid & 31.00 & * \\
\hline 64-19-7 & Acetic acid & 83.00 & * \\
\hline $6423-43-4$ & Propylene glycol dinitrate & 1.10 & \\
\hline $64-67-5$ & Diethyl sulfate & $* *$ & \\
\hline 6607 & Picloram & 33.00 & \\
\hline $67-56-1$ & Methyl alcohol & 870.00 & * \\
\hline $67-63-0$ & Isopropyl alcohol & 3300.00 & * \\
\hline 67-64-1 & Acetone & 5900.00 & * \\
\hline$\longdiv { 6 7 - 6 6 - 3 }$ & Chloroform & 0.0430000 & * \\
\hline $67-72-1$ & Hexachloroethane & 32.00 & * \\
\hline
\end{tabular}


DOE/RL-2000-21, Rev. 0

04/2000

\begin{tabular}{|c|c|c|c|}
\hline CAS \# & Substance & ASIL & In inventory \\
\hline $68-11-1$ & Thioglycolic acid & 13.00 & \\
\hline $68-12-2$ & Dimethylformamide & 30.00 & * \\
\hline $681-84-5$ & Methyl silicate & 20.00 & \\
\hline $684-16-2$ & Hexafluoroacetone & 2.30 & \\
\hline $68476-85-7$ & Liquified petroleum gas & 6000.00 & \\
\hline $684-93-5$ & N-Nitroso-N-methylurea & $* *$ & \\
\hline 6923-22-4 & Monocrotophos & 0.83 & \\
\hline $71-23-8$ & n-Propyl alcohol & 1600.00 & \\
\hline $71-36-3$ & n-Butyl alcohol & 500.00 & * \\
\hline $71-43-2$ & Benzene & 0.1200000 & * \\
\hline $71-55-6$ & Methyl chloroform (1,1,1-Trichloroethane) & 6400.00 & * \\
\hline $72-20-8$ & Endrin & 0.33 & * \\
\hline $72-43-5$ & Methoxychlor & 33.00 & \\
\hline $7429-90-5$ & Aluminum, $\mathrm{Al}$ alkyls & 6.70 & * \\
\hline $7429-90-5$ & Aluminum, as $\mathrm{AL}$ metal dust & 33.00 & * \\
\hline $7429-90-5$ & Aluminum, as AL pyro powders & 17.00 & * \\
\hline $7429-90-5$ & Aluminum, as Al soluble salts & 6.70 & * \\
\hline $7429-90-5$ & Aluminum, as Al welding fumes & 17.00 & * \\
\hline $7439-96-5$ & Manganese dust \& compounds & 0.40 & \\
\hline $7439-96-5$ & Manganese fume & 3.30 & \\
\hline $7439-97-6$ & Mercury, Aryl \& inorganic cmpd & 0.33 & $*$ \\
\hline $7439-97-6$ & Mercury, as $\mathrm{Hg} \mathrm{Alkyl} \mathrm{compounds}$ & 0.33 & $*$ \\
\hline 7439-98-7 & Molybdenum, as Mo soluble cpds & 17.00 & * \\
\hline $7439-98-7$ & Molybdenum, insoluble cpds & 33.00 & * \\
\hline $7440-02-0$ & $\begin{array}{l}\text { Nickel and compounds (as nickel subsulfide or nickel } \\
\text { refinery dust) }\end{array}$ & 0.0021000 & * \\
\hline $7440-06-4$ & Platinum, Metal & 3.30 & \\
\hline $7440-16-6$ & Rhodium Metal & 3.30 & * \\
\hline $7440-16-6$ & Rhodium, Insoluble compounds & 3.30 & * \\
\hline $7440-16-6$ & Rhodium, Soluble compounds & 0.03 & * \\
\hline $7440-22-4$ & Silver, Metal & 0.33 & * \\
\hline $7440-22-4$ & Silver, soluble compounds as $\mathrm{Ag}$ & 0.033 & * \\
\hline $7440-25-7$ & Tantalum, metal \& oxide dusts & 17.00 & \\
\hline $7440-28-0$ & Thallium, soluble compounds, Tl & 0.33 & \\
\hline $7440-31-5$ & Tin, Metal & 6.70 & \\
\hline $7440-31-5$ & Tin, oxide \& inorganic except $\mathrm{SnH} 4$ & 6.70 & \\
\hline $7440-33-7$ & Tungsten, Insoluble compounds & 17.00 & \\
\hline $7440-33-7$ & Tungsten, Soluble compounds & 3.30 & \\
\hline $7440-36-0$ & Antimony \& compounds as $\mathrm{Sb}$ & 1.70 & * \\
\hline $7440-38-2$ & Arsenic and inorganic arsenic compounds & 0.0002300 & * \\
\hline $7440-39-3$ & Barium, soluble compounds $\mathrm{Ba}$ & 1.70 & * \\
\hline $7440-41-7$ & Beryllium and compounds & 0.0004200 & * \\
\hline $7440-43-9$ & Cadmium and compounds & 0.0005600 & * \\
\hline $7440-47-3$ & Chromium (II) compounds, as $\mathrm{Cr}$ & 1.70 & * \\
\hline $7440-47-3$ & Chromium (III) compounds, $\mathrm{Cr}$ & 1.70 & * \\
\hline $7440-47-3$ & Chromium (metal) & 1.70 & * \\
\hline $7440-47-3$ & Chromium, hexavalent metal and compounds & 0.0000830 & * \\
\hline $7440-48-4$ & Cobalt as Co metal Dust and fume & 0.17 & * \\
\hline $7440-50-8$ & Copper, Dusts and mists, as $\mathrm{Cu}$ & 3.30 & * \\
\hline $7440-50-8$ & Copper, Fume & 0.67 & * \\
\hline
\end{tabular}


DOE/RL-2000-21, Rev. 0

$04 / 2000$

\begin{tabular}{|c|c|c|c|}
\hline CAS \# & Substance & ASIL & In inventory \\
\hline $7440-58-6$ & Hafnium & 1.70 & \\
\hline $7440-61-1$ & Uranium, insoluble \& soluble & 0.67 & * \\
\hline $7440-65-5$ & Yttrium, metal and cpds as Y & 3.30 & \\
\hline $7440-67-7$ & Zirconium compounds, as $\mathrm{Zr}$ & 17.00 & * \\
\hline $7440-74-6$ & Indium, \& compounds as In & 0.33 & \\
\hline $74-83-9$ & Methyl bromide & 5.00 & $\bar{*}$ \\
\hline $74-87-3$ & Methyl chloride & 340.00 & * \\
\hline $74-88-4$ & Methyl iodide & 40.00 & * \\
\hline $74-89-5$ & Methylamine & 43.00 & * \\
\hline $74-90-8$ & Hydrogen cyanide & 37.00 & \\
\hline $74-93-1$ & Methyl mercaptan & 3.30 & \\
\hline $74-96-4$ & Ethyl bromide & 3000.00 & \\
\hline $74-97-5$ & Chlorobromomethane & 3500.00 & * \\
\hline $74-99-7$ & Methyl acetylene & 5500.00 & \\
\hline $75-00-3$ & Ethyl chloride & 10000.00 & * \\
\hline $75-01-4$ & Vinyl chloride & 0.0120000 & $*$ \\
\hline $75-04-7$ & Ethylamine & 60.00 & \\
\hline $75-05-8$ & Acetonitrile & 220.00 & * \\
\hline $75-07-0$ & Acetaldehyde & 0.4500000 & * \\
\hline $75-08-1$ & Ethyl mercaptan & 4.30 & \\
\hline $75-09-2$ & Dichloromethane-(methylene chloride) & 0.5600000 & * \\
\hline $75-12-7$ & Formamide & 60.00 & * \\
\hline $75-15-0$ & Carbon disulfide & 100.00 & * \\
\hline $75-21-8$ & Ethylene oxide & 0.0100000 & * \\
\hline $75-25-2$ & Bromoform & 0.9100000 & \\
\hline $75-31-0$ & Isopropylamine & 40.00 & \\
\hline $75-34-3$ & 1,1-Dichloroethane & 2700.00 & * \\
\hline $75-35-4$ & Vinylidene chloride & 67.00 & * \\
\hline $75-43-4$ & Dichlorofluoromethane & 130.00 & \\
\hline $75-44-5$ & Phosgene & 1.30 & \\
\hline $75-45-6$ & Chlorodifluoromethane & 12000.00 & * \\
\hline $75-47-8$ & Iodoform & 33.00 & \\
\hline $75-50-3$ & Trimethylamine & 80.00 & \\
\hline $7550-45-0$ & Titanium tetrachloride & $* *$ & \\
\hline $75-52-5$ & Nitromethane & 830.00 & $*$ \\
\hline $7553-56-2$ & Iodine & 3.30 & * \\
\hline $75-55-8$ & Propylene imine & 16.00 & \\
\hline $75-56-9$ & Propylene oxide & 0.2700000 & \\
\hline $75-61-6$ & Difluorodibromomethane & 2900.00 & \\
\hline $75-63-8$ & Trifluorobromomethane & 20000.00 & \\
\hline $75-65-0$ & tert-Butyl alcohol & 1000.00 & * \\
\hline $75-69-4$ & Trichlorofluoromethane & 19000.00 & * \\
\hline $75-71-8$ & Dichlorodifluoromethane & 16000.00 & * \\
\hline $7572-29-4$ & Dichloroacetylene & 1.30 & \\
\hline $75-74-1$ & Tetramethyl lead, as $\mathrm{Pb}$ & 0.50 & \\
\hline $7580-67-8$ & Lithium hydride & 0.08 & \\
\hline $75-99-0$ & 2,2-Dichloropropionic acid & 19.00 & \\
\hline 76-03-9 & Trichloroacetic acid & 22.00 & * \\
\hline $76-06-2$ & Chloropicrin & 2.20 & \\
\hline $76-11-9$ & 1,1,1,2-Tetrachloro-2,2-difluoroethane & 14000.00 & \\
\hline
\end{tabular}




\begin{tabular}{|c|c|c|c|}
\hline CAS\# & Substance & ASIL & In inventory \\
\hline $76-12-0$ & $1,1,2,2$-Tetrachloro-1,2-difluoroethane & 14000.00 & \\
\hline 76-13-1 & 1,1,2-Trichloro-1,2,2-trifluorethane & 27000.00 & * \\
\hline $76-14-2$ & Dichlorotetrafluofoethane & 23000.00 & \\
\hline $76-15-3$ & Chloropentafluoroethane & 21000.00 & \\
\hline $7616-94-6$ & Perchloryl fluoride & 43.00 & \\
\hline $76-22-2$ & Camphor, synthetic & 40.00 & * \\
\hline $7631-90-5$ & Sodium bisulfite & 17.00 & * \\
\hline $764-41-0$ & 1,4-Dichloro-2-butene & 0.0003800 & \\
\hline $76-44-8$ & Heptachlor & 0.0007700 & * \\
\hline $7646-85-7$ & Zinc chloride fume & 3.30 & * \\
\hline $7647-01-0$ & Hydrogen chloride & 7.00 & * \\
\hline $7664-38-2$ & Phosphoric acid & 3.30 & $*$ \\
\hline $7664-39-3$ & Hydrogen fluoride, as $\mathrm{F}$ & 8.70 & * \\
\hline $7664-41-7$ & Ammonia & 100.00 & * \\
\hline $7664-93-9$ & Sulfuric acid & 3.30 & * \\
\hline $76737-07-2$ & Boron trifluoride & 9.30 & \\
\hline $7681-57-4$ & Sodium metabisulfite & 17.00 & \\
\hline $768-52-5$ & N-Isopropylaniline & 37.00 & \\
\hline $7697-37-2$ & Nitric acid & 17.00 & * \\
\hline $7719-09-7$ & Thionyl chloride & 16.00 & \\
\hline $7719-12-2$ & Phosphorus trichloride & 3.70 & \\
\hline $7722-84-1$ & \begin{tabular}{|l|} 
Hydrogen peroxide \\
\end{tabular} & 4.70 & * \\
\hline $7722-88-5$ & Tetrasodium pyrophosphate & 17.00 & * \\
\hline $7723-14-0$ & Phosphorus & 0.33 & * \\
\hline $7726-95-6$ & Bromine & 2.20 & \\
\hline $77-47-4$ & Hexachlorocyclopentadiene & 0.33 & \\
\hline $7758-97-6$ & Lead chromate, as $\mathrm{Cr}$ & 0.04 & * \\
\hline $7773-06-0$ & Ammonium sulfamate & 33.00 & \\
\hline $77-73-6$ & Dicyclopentadiene & 100.00 & * \\
\hline $77-78-1$ & Dimethyl sulfate & 1.7 & * \\
\hline $7782-41-4$ & Fluorine & 5.30 & \\
\hline $7782-49-2$ & Selenium compounds, as $\mathrm{Se}$ & 0.67 & * \\
\hline $7782-50-5$ & Chlorine & 5.00 & \\
\hline $7782-65-2$ & Germanium tetrahydride & 2.10 & \\
\hline $7783-06-4$ & Hydrogen sulfide & 0.90 & \\
\hline $7783-07-5$ & Hydrogen selenide, as Se & 0.53 & \\
\hline $7783-41-7$ & Oxygen difluoride & 0.37 & \\
\hline $7783-54-2$ & Nitrogen trifluoride & 97.00 & \\
\hline $7783-60-0$ & Sulfur tetrafluoride & 1.50 & \\
\hline $7783-79-1$ & Selenium hexafluoride, as Se & 0.53 & \\
\hline $7783-80-4$ & Tellurium hexafluoride, as Te & 0.33 & \\
\hline $7784-42-1$ & Arsine & 0.53 & \\
\hline 7786-34-7 & Mevinphos & 0.33 & \\
\hline $7789-30-2$ & Bromine pentafluoride & 2.40 & \\
\hline $7790-91-2$ & Chlorine trifluoride & 1.30 & \\
\hline $78-00-2$ & Tetraethyl lead, as $\mathrm{Pb}$ & 0.33 & \\
\hline $7803-51-2$ & Phosphine & 1.30 & \\
\hline $7803-52-3$ & Stibine & 1.70 & \\
\hline $7803-62-5$ & Silicon tetrahydride & 22.00 & \\
\hline $78-10-4$ & Ethyl silicate & 280.00 & * \\
\hline
\end{tabular}


DOE/RL-2000-21, Rev. 0

$04 / 2000$

\begin{tabular}{|c|c|c|c|}
\hline CAS \# & Substance & ASIL & In inventory \\
\hline $78-30-8$ & Triorthocresyl phosphate & 0.33 & \\
\hline $78-34-2$ & Dioxathion & 0.67 & \\
\hline $78-59-1$ & Isophorone & 93.00 & \\
\hline $78-83-1$ & Isobutyl alcohol & 510.00 & * \\
\hline $78-87-5$ & 1,2-Dichloropropane & 4 & * \\
\hline $78-92-2$ & sec-Butyl alcohol & 1000.00 & * \\
\hline $78-93-3$ & Methyl ethyl ketone (MEK) & 1000.00 & * \\
\hline $79-00-5$ & 1,1,2-Trichloroethane & 180.00 & * \\
\hline 79-01-6 & Trichloroethylene & 0.5900000 & * \\
\hline 79-04-9 & Chloroacetyl chloride & 0.67 & \\
\hline 79-06-1 & Acrylamide & 0.0007700 & \\
\hline $79-09-4$ & Propionic acid & 100.00 & * \\
\hline $79-10-7$ & Acrylic acid & 0.30 & * \\
\hline $79-11-8$ & Chloroacetic acid & $* *$ & * \\
\hline $79-20-9$ & Methyl acetate & 2000.00 & \\
\hline $79-24-3$ & Nitroethane & 1000.00 & \\
\hline $79-27-6$ & Acetylene tetrabromide & 47.00 & * \\
\hline 79-34-5 & 1,1,2,2-Tetrachloroethane & 23.00 & * \\
\hline $79-41-4$ & Methacrylic acid & 230.00 & \\
\hline $79-44-7$ & Dimethyl carbamoyl chloride & $* *$ & \\
\hline $79-46-9$ & 2-Nitropropane & 0.0003700 & \\
\hline $8001-35-2$ & Toxaphene & 0.0031000 & \\
\hline $8002-74-2$ & Parafin wax fume & 6.70 & \\
\hline $8003-\overline{34-7}$ & Pyrethrum & 1.70 & \\
\hline $8006-64-2$ & Turpentine & 1900.00 & \\
\hline $8012-95-1$ & Oil mist, mineral & 17.00 & * \\
\hline $8022-00-2$ & Methyl demeton & 1.70 & \\
\hline $8032-32-4$ & VM \& P Naphtha & 4600.00 & * \\
\hline $8052-42-4$ & Asphalt (petroleum) fumes & 17.00 & * \\
\hline $80-62-6$ & Methyl methacrylate & 1400.00 & * \\
\hline $8065-48-3$ & Demeton & 0.37 & \\
\hline $81-81-2$ & Warfarin & 0.33 & \\
\hline $822-06-0$ & Hexamethylene diisocyanate & 0.11 & \\
\hline $82-68-8$ & Pentachloronitrobenzene (quintobenzene) & 1.70 & \\
\hline $83-26-1$ & Pindone & 0.033 & \\
\hline $83-79-4$ & Rotenone & 17.00 & \\
\hline $84-66-2$ & Diethyl phthalate & 17.00 & \\
\hline $84-74-2$ & Dibutyl phthalate & 17.00 & * \\
\hline $85-00-7$ & Diquat & 1.70 & \\
\hline $85-44-9$ & Phthalic anhydride & 20.00 & \\
\hline 86-50-0 & Azinphos-methyl & 0.67 & \\
\hline 86-88-4 & ANTU & 1.00 & \\
\hline $87-68-3$ & Hexachlorobutadiene & 0.70 & * \\
\hline $87-86-5$ & Pentachlorophenol & 0.3300000 & * \\
\hline $88-06-2$ & 2,4,6-Trichlorophenol & 0.3200000 & \\
\hline $88-72-2$ & Nitrotoluene & 37.00 & \\
\hline $88-89-1$ & Picric acid & 0.33 & * \\
\hline $89-72-5$ & o-sec-Butylphenol & 100.00 & \\
\hline $90-04-0$ & o-Anisidine & 1.7 & \\
\hline $91-20-3$ & Napthalene & 170.00 & * \\
\hline
\end{tabular}


DOE/RL-2000-21, Rev. 0

$04 / 2000$

\begin{tabular}{|c|c|c|c|}
\hline CAS \# & Substance & ASIL & In inventory \\
\hline $91-22-5$ & Quinoline & ** & $*$ \\
\hline 91-94-1 & 3,3'-Dichlorobenzidine & 0.0770000 & \\
\hline $924-16-3$ & N-Nitrosodi-n-butylamine & 0.0006300 & \\
\hline $92-52-4$ & Biphenyl & 4.30 & \\
\hline $92-84-2$ & Phenothiazine & 1.70 & \\
\hline $92-87-5$ & Benzidine and its salts & 0.0000150 & \\
\hline 92-93-3 & 4-Nitrobiphenyl & $* *$ & \\
\hline 93-76-5 & $2,4,5-\mathrm{T}$ & 33.00 & \\
\hline $94-36-0$ & Benzoyl Peroxide & 17.00 & \\
\hline $944-22-9$ & Fonofos & 0.33 & \\
\hline $94-75-7$ & 2,4-D and esters & 33 & * \\
\hline $95-13-6$ & Indene & 160.00 & \# \\
\hline $95-49-8$ & o-Chlorotoluene & 860.00 & \\
\hline $95-50-1$ & o-Dichlorobenzene (1,2-Dichlorobenzene) & 1000.00 & \\
\hline $95-53-4$ & o-Toluidine & 0.1400000 & \\
\hline $95-80-7$ & 2,4-Toluene diamine & 0.0110000 & \\
\hline $95-95-4$ & 2,4,5-Trichlorophenol & *** & * \\
\hline $96-12-8$ & 1,2-Dibromo-3-chloropropane & 0.20 & \\
\hline $96-18-4$ & 1,2,3-Trichloropropane & 200.00 & \\
\hline $96-22-0$ & Diethyl ketone & 2300.00 & \\
\hline $96-33-3$ & Methyl acrylate & 120.00 & \\
\hline $96-45-7$ & Ethylene thiourea & 1.0000000 & \\
\hline $96-69-5$ & 4,4-Thiobis(6-tert, butyl-m-cresol) & 33.00 & \\
\hline $96-9-3$ & Styrene oxide & ** & \\
\hline $97-77-8$ & Disulfiram & 6.70 & \\
\hline $98-00-1$ & Furfuryl alcohol & 130.00 & * \\
\hline $98-01-1$ & Furfural & 26.00 & * \\
\hline $98-07-7$ & Benzotrichloride & *** & \\
\hline $98-51-1$ & p-tert-Butyltoluene & 200.00 & \\
\hline $98-82-2$ & Cumene & 820.00 & \\
\hline $98-83-9$ & a-Methyl styrene & 810.00 & \\
\hline $98-86-2$ & Acetophenone & *** & * \\
\hline 98-95-3 & Nitrobenzene & 1.70 & * \\
\hline $999-61-1$ & 2-Hydroxypropyl acrylate & 9.30 & \\
\hline C7439-97-6 & Mercury, vapors except alkyl & 0.17 & \\
\hline C7440-31-5 & Tin, Organic compounds, as Sn & 0.33 & \\
\hline
\end{tabular}

** TAPs that do not have a listed ASIL were assigned an ASIL equal to the lowest Class A or Class B ASIL listed in WAC 173-460. For mixtures of compounds, the smallest ASIL was used, per WAC 173-460-050(4).

CAS \# = Chemical Abstracts Service number.

ASIL = acceptable source impact level. 
DOE/RL-2000-21, Rev. 0

$04 / 2000$

This page intentionally left blank. 
The query from the SWITS database report (10-19-99) was placed in an Excel spreadsheet. The spreadsheet was reduced by eliminating containers that had radioactive constituents only. Further reduction was achieved by eliminating lab packs and constituents that were not chemicals (e.g., wood, paper, plastic, etc.). The resultant spreadsheet contained almost 51,000 lines of data. The 21 columns used in the spreadsheet are described as follows.

- Column A This is the package identification number.

- Column B This is the Chemical Abstract System number.

- Column C This is the name of the chemical component.

- Column D This is the ASIL (in micrograms per cubic meter) from WAC 173-460.

- Column E This is the weight of the chemical component (in pounds).

- Column F This is the calculated offsite concentration (in micrograms per cubic meter), multiplying the Column E value (converted to grams) by the appropriate unit concentration factor (ISC3), either 24-hour or annual, depending on class.

- Column G The offsite concentration is compared to the ASIL (below ASIL= yes). All values returned a "Yes" response, except for compounds identified in Column M as "Evaluate".

- Column $\mathrm{H}$ This is the density of the chemical (specific gravity, unitless) from the TOMES database.

- Column I This is the vapor pressure (in $\mathrm{mm} \mathrm{Hg}$ ) of the chemical from the TOMES database.

- Column J

This is the molecular weight (grams per mole) of the chemical from the TOMES database.

- Column K

This is the theoretical chemical release (in pounds), using the ideal gas law. The calculation assumes 1 vapor space exchange per day, 365 days per year, and 55 gallons of the pure chemical at $25^{\circ} \mathrm{C}\left(303^{\circ} \mathrm{K}\right)$, using Columns $\mathrm{H}, \mathrm{I}$, and $\mathrm{J}$ data.

- Column $\mathrm{L} \quad$ This is the estimated maximum release (in pounds), using the smaller value in Column $\mathrm{E}$ or Column $\mathrm{K}$, because it is not possible to release more than what is actually present. 
- Column M
- Column N

- Column O

- Column P

- Column Q

- Column R

- Column S

- Column T

- Column U

The estimated maximum release is compared to the SQER in Column O (above SQER = yes). All values returned a "No" response or an "Evaluate" response, if no SQER existed. All "Evaluate" responses were determined to have vapor pressure values of essentially zero, and so were deemed nonvolatile TAPs.

This is the class (A or B) of the toxic air pollutant, as listed in WAC 173-460.

This is the SQER value, calculated from the ASIL value in Column D, duplicating the Class A or Class B SQER tables in WAC 173-460-080. Class A compounds with ASILS below 0.001 returned a response of "NO SQE", which triggered a response of "Evaluate" in Column $\mathrm{M}$.

This is the ASIL threshold (in pounds), using the appropriate unit concentration factor (ISC3) and averaging period (24-hour or 365-day), depending on whether the compound is listed as class A or Class B in Column N. This formula calculated the amount of the compound that would have to be released to exceed the ASIL concentration (in micrograms per cubic meter) at the site boundary.

This is the ASIL threshold (in tons), reflecting the annual averaging period for Class A compounds, and the 24-hour averaging period for Class B Compounds.

This is the maximum theoretical release per drum (in pounds per year). Using the ideal gas law, and assuming 1 vapor space exchange per day, 365 days per year, and that 1 percent of the 55 gallons volume is the pure chemical at $25^{\circ} \mathrm{C}$ ( $\left.303^{\circ} \mathrm{K}\right)$, using Columns $\mathrm{H}, \mathrm{I}$, and $\mathrm{J}$ data.

This column determines whether it is possible to exceed the ASIL. This evaluation assumes 20 percent of the total capacity of the CWC (88,500 drum equivalents) is vented and that the chemical is released at the maximum rate shown in Column R. All values resulted in a response of "No".

This was a determination made to evaluate the total VOC emissions to compare to the 2 ton threshold in WAC 173-400. Based on vapor pressures, molecular formulas, and regulatory exemptions, a response of "Yes" was assigned to compounds that would be considered VOCs.

This column used the estimated maximum release (in pounds) shown in Column $\mathrm{L}$, for the compounds that were assigned a "Yes" value in Column $\mathrm{T}$. The sum of values in this column was the total theoretical release of VOCs that are regulated as TAPs. A similar exercise was done with a separate spreadsheet of chemicals that are not regulated as TAPs, but are considered VOCs. The combined total theoretical emissions of VOCs was less than 6000 pounds (generated over a 20 -year period), which was used in the emissions estimation described in Section 7.0. 


\section{DISTRIBUTION}

MSIN

Washington State Department of Ecology

J. L. Hensley (2)

B5-18

Mike A. Wilson, Program Manager

Nuclear Waste Program

Washington State Department of Ecology

P.O. Box 47600

Olympia, Washington $98504-7600$

J. Wilkinson

Confederated Tribes of the Umatilla Indian Nation

P.O. Box 638

Pendleton, Oregon 97801

P. Sobotta

Nez Perce Tribe

P.O. Box 365

Lapwai, Idaho 93540

R. Jim, Manager

Environmental Restoration/Waste Management Program Yakama Nation

P.O. Box 151

Toppenish, Washington 98948

U.S. Department of Energy, Richland Operations Office

C. E. Clark

A2-15

T. Hillman-Glazier

$\mathrm{H} 0-12$

R. F. Guercia

$\mathrm{H} 0-12$

P. J. Krupin (3)

A2-15

G. L. Sinton

$\mathrm{H} 0-12$

Public Reading Room

H2-53

Fluor Hanford

M. D. Aichele

T4-04

R. B. Barmettlor

T3-28

B. M. Barnes

T3-28

R. C. Brunke

G1-37

B. L. Curn

G1-30

L. P. Diediker

G1-30

M. D. Ellefson

T3-05

R. H. Engelmann

G1-30

C. K. Girres

T3-01

E. M. Greager

G1-29

W. E. Green

G1-30

R. D. Greenwell

T4-04

R. H. Gurske

H8-73

J. W. Hales

A1-14 


\section{DISTRIBUTION}

J. E. Hyatt

MSIN

R. E. Johnson (3)

G1-32

L. D. Kamberg

G1-30

A. K. McDowell

T4-04

J. E. Mitchell

T3-05

T. L. Moore

T4-04

S. M. Oldfield

G1-32

J. O. Perkins

T4-04

L. L. Powers

G1-31

D. A. Pratt

L1-04

T4-03

S. M. Price

A0-22

K. A. Peterson

G1-37

D. R. Pyzel

T4-04

J. R. Rosser

T4-03

D. G. Saueressig

T4-04

B. L. Slettene

T4-04

G. C. Triner

T3-05

R. T. Wilde

G1-36

J. D. Williams

H8-67

J. F. Williams Jr.

G1-30

L. F. Willis

H8-73

RCRA File (D. B. Jensen)

G1-27

FH Legal (S. B. Cherry)

B3-15

LB/File

G1-30

AOP File

G1-30

Pacific Northwest National Laboratory

Hanford Technical Library

P8-55

Lockheed Martin Services, Inc.

Central Files

B1-07

DPC

H6-08

EDMC (2)

H6-08 